Historic, Archive Document

Do not assume content reflects current scientific knowledge, policies, or practices. 



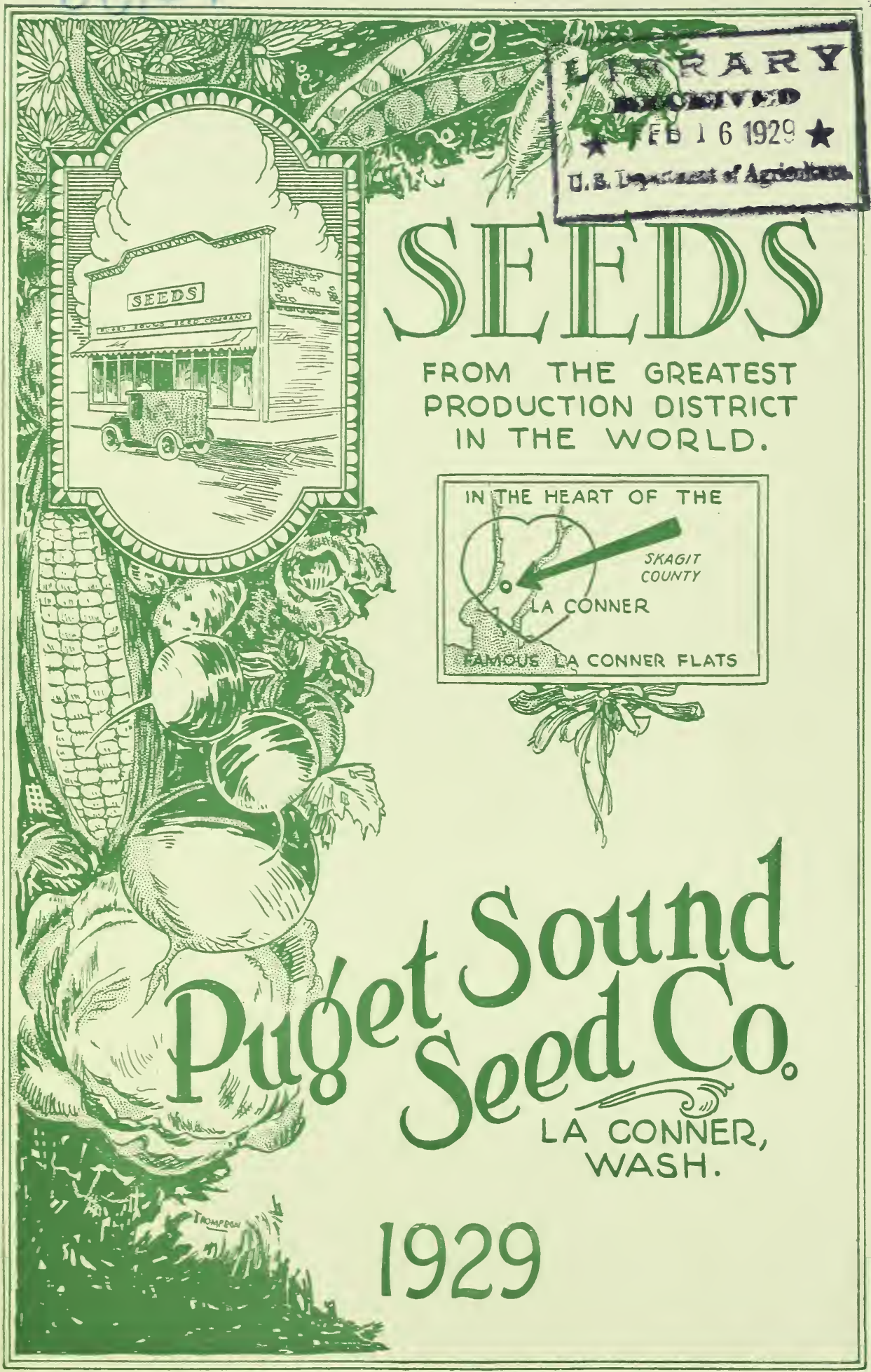




\section{Seed and Plant Guide}

W e bring you another Seed Annual and with it a determination to give you better service and, if possible, better seeds, when we say better seeds we mean that we are striving to place before the public the better varieties suitable for those who must get all that they can out of the Family garden, and not so much as oddities or curiosities in the plant life. Our miraculous growth in this line leads us to believe that we are accomplishing our aim,--"The best in quality that we can get for you".

If, by chance, you receive more than one copy of this edicion kindly pass it on to a neighbor or friend.

If you find there are problems about your plants or grounds that we can help you solve, do not hesitate to write us. We are at your service in all horticultural matters.

We centralize our efforts in growing seeds that are best suited for the Northwest; seeds grown in the Puget Sound district have a higher germinaticn ard vitality test than seeds grown in any other part of the world. Naturally we cannot grow everything so in such cases we try to buy Northwest grown seeds or those best suited for the Northwestern states.

In addition to our MAIL ORDERS we sell our seeds in DISPLAY CASES with your local merchant. The seed found in these cases are the same HIGH QUALITY that we serve you with in our Mail Order department. If your merchant cannot supply you write us. Do not take any substitute; see that every packet bears the name Puget Sound seed Co.

When making out your order take just a little more time at it and place on the reverse side of the order blank the names and address, including the R. F. D. route or street number, of friends interested in gardening, and we will enclose with the order extra flower or vegetable seed.

We pay coming and going; our new Business Reply Envelope needs no postage stamp. Just place your order together with your check, in it and any Postmaster will receive it as first class mail. Your order will also go forward prepaid, except where noted.

FREE OFFER-With every order of Flower or Vegetable seed packets, amounting to $\$ 2.00$ we will give, Free, one-half dozen Gladicli bulbs or with every $\$ 1.50$ order cne Dahlia tuber, if you mention it, our selection.

OUR GLADIOLI OFFER-Numbers 20 and 32 should nct be overlooked as well as those of Dahlias numbering 33 to 38 inclusive. You will find real values there

All seeds and plants will be delivered to your nearest Post Office or where you have the R. F. D. to your mail box, PREPAID, at the price quoted in this catalog with the exceptions of Grains, Grasses and Field Corm, orders from Alaska and Dominion of Canada. All orders from beyond the 5 th zone add 5 cents per pound for postage.

Accompany all orders with Money Order, Bank Draft or your personal check. Cash or Stamps accepted for small amounts.

See that your Name and Address is given plainly, in full. 


\section{Novelties for 1929}

\section{Sweet Peas}

RUFFLED ROSE-This new ruffled sweet pea even surpasses the Fluffy-Ruffles in size and the flowers are truly gigantic. Six sprays make a bunch more massive than twelve of the ordinary sweet peas. Color is a soft but rich shade of rose with an oversheen of salmon. Packet (20 seeds) 25c.

FLUFFY RUFFLES-A great big flower, vigorous and free blooming, first of the Ruffled sweet peas. A new type, duplexed and frilled, with long stems well proportioned sprays of four almost globular flowers. A lovely rich rosepink, a gleam of soft salmon, and a bright creamy undertone blended into a cream-pink. Packet $15 \mathrm{c}$.

IVORY PICTURE-A flower of great size and good form. A rich old ivory tint. Packet 15c.

One packet each of the New Sweet Peas for $45 \mathrm{c}$

\section{New Race of Gladioli with Laciniated Petals}

COMET-A deep golden yellow Laciniated variety with large, red throat blotches. A very rich deep yellow of pleasing appearance. Each 50c.

LAVENDER BEAUTY-Pinkish lavender flaked deeper lavender. Lower petals a little lighter in the throat with slight throat markings and narrow central lines. Each $75 \mathrm{c}$.

LACINATUS-Beautiful rose-pink and under good culture will reach the size of three and one half to four inches in diameter. Spike is slender, graceful and of good height. A large bulb will produce four and five spikes of blooms. Each 30c.

See Collection No. 20

\section{New Ruffled Gladioli}

CRINKLES-Deep peach-blossom pink. Intensely ruffled. This creation is the best of the ruffled varieties in the deeper pinks. Each 30c.

LILAC GLORY - Large flowers and many of them opened at a time; soft lilac rose-pink; beautiful deeper rose-pink throat. Each 25c.

VIOLET GLORY-Massive flowers; rich self colored deep violet; deeper throat. Medium ruffled. Each 25c.

See Collection No. 21

\section{Plain Petaled Gladioli}

KUNDREDS YELLOW FAVORITE-Entire face of the flower deep-yellow with deeper yellow on lower petals. Throat finely feathered and penciled soft-red. The plant is tall and stately. Each $35 \mathrm{c}$.

JOHN T. PIRIE-An exceptionally colored variety; a sort of mahogany-brown with yellow bordered dark mahogany-brown throat. In a class by itself. Each 30c.

MULLIONAIRE-Tall elegant plant, with many flowers open at a time; flowers rich velvety crimson, beautifully flaked geranium-red; lower petals flaked darker; throat deeper with creamy blotches. Each $40 \mathrm{c}$.

TIGER-Large perfectly placed, wide open flowers of tiger-like markings; ground color deep smoky-blue; outer edge of petals finest salmon-red flaking; throat red with outer portions blotched with white. Each 50c.

See Collection No. 22

FREE OFFER

We will give One Half dozen Mixed Hybrid Gladioli with any order of garden or flower seeds amounting to $\$ 2.00$. Just mention it. 


\section{- GARDEN SEEDS .}

\section{Plant A Vegetable Garden}

Our catalog describes all of the best standard varieties and the newer kinds that have become popular.

It is surprising how small a piece of ground is needed to supply a family of average size with fresh vegetables through the whole season. A piece of ground, say, thirty feet by forty feet, will do it. In these days of high prices there are many sorts of vegetables that it more than pays to grow at home. In comparison with the ridiculously small cost, the return surely does warrant the effort.

\section{Asparagus}

G I A N T WASHINGTON - Genuine rust-resistant strain. This variety is stronger and more productive, owing to its great vigor, than the old varieties and can be cut sooner from time of planting. Packet $5 c$; ounce $25 c$; $1 / 4-1 b .75 c$.

MARY WASHINGTON-A strain of the Giant Washington, but a little earlier and larger, but equally rust-resistant. Packet 5c; ounce 25c; 1/4-1b. 75c.:
PALMETTO-This is the best of the old sorts; green shoots, very prolific. Packet $5 \mathrm{c}$; ounce $15 \mathrm{c}$; 1/4-1b. $35 \mathrm{c} ; 1-1 \mathrm{~b}$. $\$ 1.00$.

\section{PLANTS}

WASHINGTON VARIETIES - No. 1 plants, 40c doz.; 50 plants, $\$ 1.00 ; 100$ plants for $\$ 1.75$.

PALMETTO - 1-year-old plants 30c; 50 plants for $65 \mathrm{c}$; 100 plants for $\$ 1.15$. 2-year-old plants $40 \mathrm{c}$; 50 plants for $90 \mathrm{c}$; 100 plants for $\$ 1.50$.

\section{BEANS--Bush}

DWARF HORTICULTURAL - The green pods are medium length and when nearly developed are splashed with red. The green shelled beans are tender and fine flavored. Packet 10c; 1/2-lb. 20c; 1-lb. 35c.

PENCIL POD BLACK WAX-Hardy and prolific and of fine quality. The pods are long, round and free from strings. Desirable for canning. Packet 10c; $1 / 2-1 b .20$ c; $1-1 b .35$ c.

\section{BURPEE'S STRINGLESS GREEN} POD-For a snap bean this variety is unequaled. The pods are medium in length, slightly curved and thick, meaty and juicy, with no signs of a string. The finest green podded bush bean. Packet $10 c ; 1 / 2-1 b .20 c ; 1-1 b .35 c$.

IMPROVED GOLDEN WAX-Large podded and a heavy yielder. Excellent both as a snap and as a shell bean; cooks quickly. Packet 10c; $1 / 2-1 b$. 20c 1-1b. $35 \mathrm{c}$.

DAVIS WHITE WAX-Rustless and very hardy. The dry bean is kidneyshaped, clear white. A favorite for baking. Packet 10c; $1 / 2-1 b .20 c ; 1-1 b .35 c$.

SWEDISH BROWN BEAN-An excellent dry bean; fine for baking. Packet $10 c ; 1 / 2-1 b$. 20c; $1-1 b$. 35c.

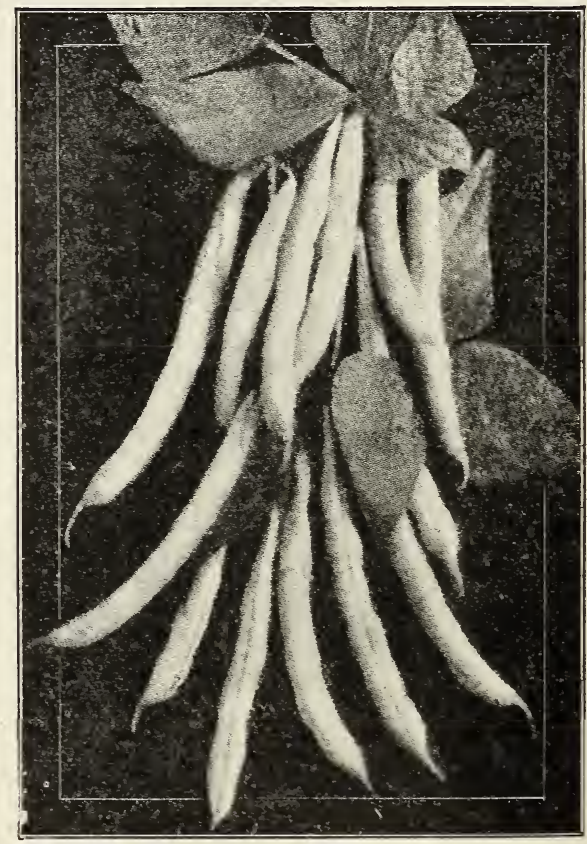

IMPROVED GOLDEN WAX 


\section{BEANS-- (Cominimed ) \\ CLIMIBING OR POLE}

Postpaid, Packet 10c; 1/2-1b. 20c; 1-1b. 35c

BURGER'S STRINGLESS - White seeded and similar to Kentucky Wonder, but produces heavier and is free from strings. Very meaty and excellent in flavor and quality.

KENTUCKY WONDER (or Old Homestead)-The pods are almost stringless and hang in large clusters from top to bottom of pole.

KENTUCKY WONDER WAX-Similar to the Kentucky Wonder. Commences to bear when plants are small and keeps it up until the frost. Sometimes known as the Pride of the Garden.

DUTCH CASE KNIFE (or Scallaboon) -Early productive; and fine flavor, good as a snap or shell bean. The pods are large, green and flat.

OREGON LIMA-A large pole lima, early and well suited for the Northwest as our stock is locally grown. Fine for a butter bean or for winter use.

SCARLET RUNNER-A favorite for a shell bean and also for its flowers, which are a bright scarlet. Seeds broad and kidney shaped.

\section{Table Beets}

Packet 5c; Ounce 10c; 1/4-1b. 25c; 1-1b. 80c

DETROIT DARK RED-Roots round, very uniform, rich dark red and a favorite of the beets. The best for the cannery.

EXTRA EARLY EGYPTIAN-The roots are rather flattened shape and the flesh is dark red and of fine quality. An early beet with small leaves.

EARLY WONDER-A deep blood red nearly globe-shaped with a small tap root, one of the earliest and most uniform for bunching. Fine for late planting.

EARLY BL()OD TURNIP-A standard medium early variety, excellent for summer and autumn use.

HALF LONG UEEP BLOOD-An entirely distinct rariety; smooth; flesh a dark red, and never becomes woody.

\section{Sugar Beets}

Packets 5c; ounce $10 \mathrm{c} ; 1 / 4-\mathrm{lb} .20 \mathrm{c} ; 1-\mathrm{lb} .50 \mathrm{c}$

LINE WANZLEBEN-Used both for stock feeding and for sugar.

\section{Swiss Chard}

Packet 5c; Ounce 10c; 1/4-lb. 25c; 1-1b 80c

LUCULLUS-Superior to the beet tops for greens and produces heavier. Fine for chickens.

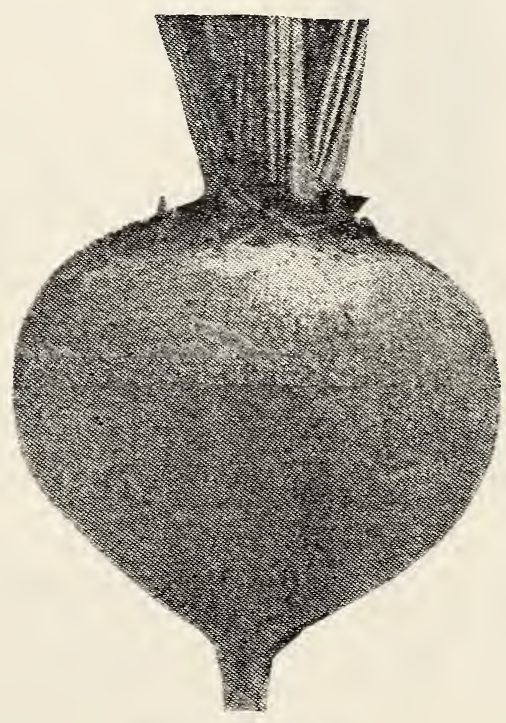

DETROIT DARK RED

Knowing the germination period of the different kinds of seeds and with the testing apparatus we have, the Puget Sound Seed Company is able to guarantee all seeds to the full amount of the purchase price. 


\section{Mangel-Wurzel or Cow Beets}

$1 / 2-$ lb. 20c; 1-lb. 35c; 5-lb. $\$ 1.50 ; 10-$ lb. $\$ 2.75$

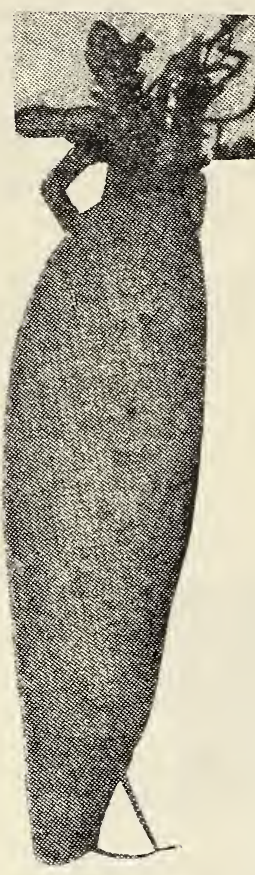

SLUDSTRUP
DANISH SLUDSTRUP-Long, reddish-yellow, rich in food value and grows well above ground.

GIANT HALF SUGAR-Flesh white and exceedingly rich, a good feeder and easily pulled.

M A $\mathbf{M}$ M $\mathbf{O}$ T $\mathbf{T}$ LONG RED-Grows very large and is a little coarser than the above sorts.

\section{GATE POST OR} GIANT YELLOWSimilar to the Sludstrup; flesh white and firm.

\section{GOL D E N Y E L-} LOW TANKARDS m o ot $h$, yellowfleshed; grows largely above the ground making them easy to pull.

\section{Brussels Sprouts}

Packet 5c; Ounce 20c; 1/4-lb. 65c

TALL FRENCH-The best kind for the Northwest; matures late in fall and in winter.

\section{Broccoli \\ (Winter Cauliflower)}

ST. VALENTINE'S-This is the very best sort; solid, handsome heads, white and of immense size. Good shipper. Packet $10 \mathrm{c}$; ounce $\$ 1.25$.

LARGE WHITE FRENCH-Produces fine compact heads; is very hardy. Packet $5 c$; ounce $50 \mathrm{c}$.

\section{Cauliflower}

EARLIEST OF ALL-This is a wonderful new cauliflower and surpasses the Early Snowball in every way and is recognized by the market gardeners as the leading Cauliflower for the Northwest. The large, white heads on short stems. The inner leaves fold over and protect the heart. Packet 15c; 1/4-ounce $90 \mathrm{c}$; one ounce $\$ 2.50$.

SELECTED EARLY SNOWBALL-This is the best of the old varieties; produces heads that are large, solid and extra white. Packet $10 c ; 1 / 4$ ounce $60 c$; one ounce for $\$ 1.95$.

VETCHES AUTUMN GIANT-Heads white, large, compact and well protected with leaves. Packet $5 \mathrm{c}$; ounce $50 \mathrm{c}$.

\section{FOR YOUR CONVENIENCE}

Each season we place a large selection of our seeds in our popular size packets in attractive and convenient display cases in the grocery and hardware stores of the Northwest. Thus we are enabled to extend to you a THREE-FOLD service - that of making it possible for you to make your selection of our high quality, guaranteed seeds right at home; by ordering by mail from our wholesale house here in LaConner, or coming to our store personally to make your seed purchase. In every case you get exactly the same high grade seeds, for at the end of each season all these display cases are picked up and returned to our seed house, where any left-over seeds are replaced with fresh new stock for the spring display when they again appear in the retail stores.

CAUTION: If your merchant cannot supply you, or if the supply of some particular kind of seeds in the display case is exhausted, write us; or if convenient come to our store for it. Do not take any substitute. See that each packet bears the name Puget Sound Seed Co. 


\section{Cabbage}

Packet 5c; ounce 20c; $1 / 4-\mathrm{lb} .60 \mathrm{c} ; 1-\mathrm{lb} . \$ 2.00$

(except where noted)

GOLDEN ACRE-The heads are round firm, and few outer leaves and average weight is about four pounds. The heads mature about two weeks earlier than the Early Jersey Wakefield. Fine for market gardeners. Packet $5 \mathrm{c}$; ounce $40 \mathrm{c} ; 1 / 4-\mathrm{lb}$. $\$ 1.10 ; 1-1 b$. $\$ 4.00$.

EARLY JERSEY WAKEFIELD-The next earliest and fine for the early market. Solid heads and few outside leaves and most valuable for main crop.

EARLY FLAT DUTCH-A good second early variety; compact heads, rather large and flattened; short stemmed. Good for home and market.

CHARLESTON WAKEFIELD-A little larger and later than the Early Jersey; very hardy; heads pointed.

COPENHAGEN MARKET-Good sized round heads; maturing with the Charleston Wakefield; a fine second early variety. Ounce 30c; 1-lb. 80c.

PREMIUM LATE FLAT DUTCH-A sure header, good quality and the most popular of the large varieties.

DANISH BALLHEAD-A short stemmed variety, fine ribbed and closely packed leaves; late; excellent for keeping and superior to any for sauerkraut. Ounce 30c; $1 / 1-$ lb. $80 c$.

RED DRUMHEAD-Late; large and forming a compact head; used largely for pickling.

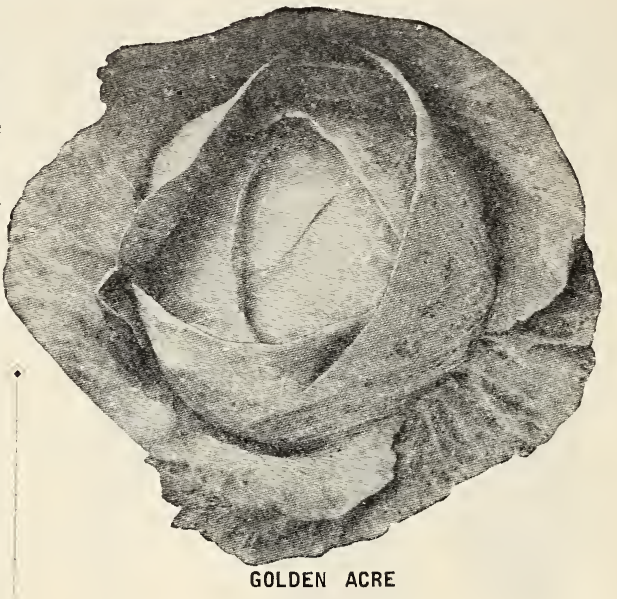

SAVOY CABBAGE-Compact heads, crisp and tender; stands cold weather well.

\section{Chinese Cabbage}

\section{(PE-TSAI)}

Also known as Chinese Celery Cabbage

Most essential requirements for successfully raising Chinese cabbage is cool weather. Sow seed in the latter part of July or in August. Large leaves of light green color with thick, white, tender stalks and heart. Packet $5 \mathrm{c}$; ounce $25 \mathrm{c}$; $1 / 4-\mathrm{lb}$. 90c. $1 / 2-1 b . \$ 1.75$.

\section{Swiss Chard}

Packet 5c; Ounce 10c; $1 / 4-\mathrm{lb}$. 25c; 1-lb. 80c

LUCULLUS-Superior to the beet tops for greens and produces heavier. Fine for chickens.

\section{LEND THIS CAT ALOG TO A FRIEND}

If you receive more than one copy of our Seed Annual hand the extra one to a friend. 


\section{Carrots}

Packet $5 c ;$ ounce $10 c ; 1 / 4-1 b .25 c ; 1 / 2-1 b$. $45 c ; 1-1 b .80 c$.

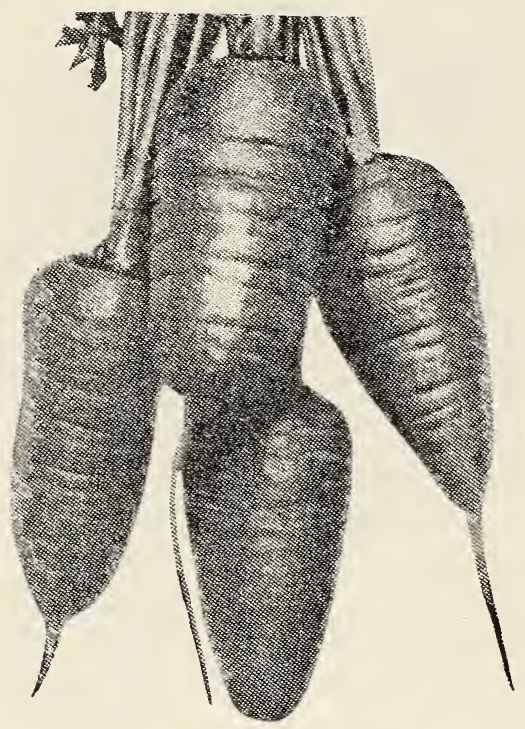

EARLY SCARLET HORN-The best early kind for general use; larger than the forcing varieties but just as fine a quality.

CHANTENAY - The roots are smooth stump-rooted and somewhat thicker at top; flesh is deep orange-red, crisp and tender.

DANVERS HALF LONG-A standard carrot but not recommended for table use compared with the Chantenay; a heavy cropper.

OXHEART-It grows very rapidly; very fine grained and sweet; roots blunt and easy to pull.

LONG ORANGE-Suited for deep soil; long red roots; good for stock feeding.

LARGE WHITE BELGIAN-Long rooted white stock carrot; grows well above ground.

IMPROVED SHORT WHITE OR MASTADON-Ranks as one of the best for stock feeding owing to its enormous productiveness; easy to harvest.

\section{Celery}

GOLDEN PLUME CELERY-An outstanding new variety of Celery. The plants are of strong growth and produce thick heavy stalks with a well-balanced heart. It is considered by many the best early Celery; matures early; quite blightresistant, but not suitable for storing. Packet 10c; $1 / 4$-ounce $65 \mathrm{c} ; 1 / 2$-ounce $\$ 1.20$.

WHITE PLUME-This celery is early and one of the best of the white varieties and is very tender. Packet $5 \mathrm{c}$; ounce 25c.

G O L D E N SELF-BLANCHING-Most popular of the celerys; the stalks are wide and the quality extra fine, also adapted for shipment. Packet $5 \mathrm{c}$; ounce $45 \mathrm{c}$.

EASY BLANCHING-An improvement over the above, being free from strings. It is also early. Packet $5 \mathrm{c}$; ounce $45 \mathrm{c}$.

CELERIAC-A turnip rooted celery and used largely for flavoring soups and stews. Very hardy. Packet $5 \mathrm{c}$; Ounce 25c.

\section{Chives}

Packet $5 \mathrm{c} ; 1 / 1$-ounce 25c; 1/2-ounce $45 \mathrm{c}$; ounce $75 \mathrm{c}$

Chives has a mild flavor of young onions and is used for soups and salads.

\section{Chickory}

LARGE ROOTED-Used for a substitute for coffee; also as an adulteration. Packet 5c: ounce 20c.

\section{Collards}

Packet 5c; ounce 15c; 1/1-lb. 40c

GEORGIA-A loose form of cabbage that is grown for greens; produces abundant supply of large succulent leaves.

\section{Cress--Garden}

\section{CURLED GARDEN CRESS-Grows} quickly and should be seeded at intervals as it seeds quickly. Packet $5 \mathrm{c}$; ounce $10 \mathrm{c}$.

\section{Corn Salad}

LARGE HEADED-A substitute for lettuce and spinach in the fall and winter. Packet 5c; ounce 20c. 


\section{Sweet Corn}

Packet $10 \mathrm{c} ; 1 / 2-\mathrm{lb} .20 \mathrm{c}$; pound $30 \mathrm{c} ; 5$ lbs. $\$ 1.35 ; 10 \mathrm{lbs}$. $\$ 2.25$

(except where noted)

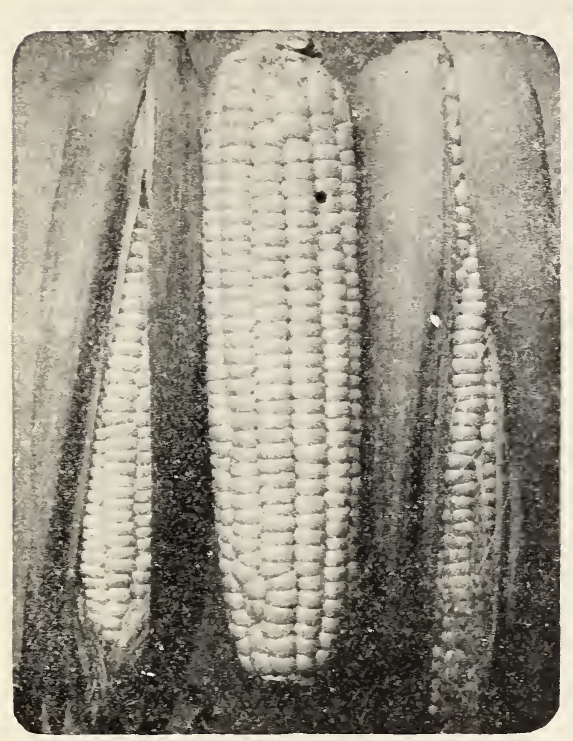

GOLDEN GIANT

EARLY SWEET-Earliest and sweetest of all white corn. Will furnish you with luscious sweet corn while other varieties are maturing, insuring sweet corn for a long season. Produces large ears.

EARLY MARKET-This is a fine largeeared sweet corn producing white grains set 12 to 14 rows to the cob. Takes well with the market gardeners.
GOLDEN EARLY MARKET-This is undoubtedly the best early yellow corn yet introduced. It is sweeter than the white varieties and earliest of the yellow sorts. The stalks are vigorous and taller than the Early Market. Packet 10c; 1, $-1 \mathrm{lb}$. 25c; 1-lb. 35c;; 5-lbs. \$1.50.

GOLDEN GIANT-The cobs are larger and the corn is better flavored than the golden bantam, and a week earlier.

GOLDEN BANTAMI-This is the original yellow sweet corn. Does not grow quite as large as the Golden Giant but has most of its fine qualities; early, productive, sweet and rich.

BLACK MEXICAN-An old variety known for its quality and sweetness.

\section{Pop Corn}

WHITE RICE-The best Pop Corn, sharp pointed grains. Our seed is fully acclimated. Packet 10c; 1/2-lb. 20c; 1-lb. 30c.

\section{Field Corn}

1 -lb 15c; 10-lbs. $\$ 1.20$

MINNESOTA No. 13-The earliest of the early yellow dent corns and one of the heaviest yielders, highly recommended for ensilage.

PRIDE OF THE NORTH-This variety like the above, is a fine corn for the Northwest and is recommended by the - Agricultural Stations for feeding.

\section{Cucumbers}

Packet 5c; ounce 15c; 1/1-lb. 45c

BOSTON PICKLING-The most popular pickling sort; medium size and vigorous.

DAVIS PERFECT-A strong vigorous grower, producing a heavy crop of uniform dark colored cucumbers. Does not turn yellow as soon as others.

EARLY WHITE SPINE (Improved)-One of the best early sorts for table use; uniformly straight; light green.
IMPROVED LONG GREEN-The leading large variety; long, dark green and tender; a good slicer and fine for sweet pickles.

LEMON CUCUMBER-Resembles a lemon both in color and form; fine for either pickling or slicing.

JAPANESE CLIMBING-Grows well on Trellises; the cucumbers are large, - white flesh, crisp and fine flavored. 


\section{Dill}

Used largely for flavoring pickles-see Herbs. Packet $5 c$; ounce $15 c$.

\section{Endive}

\section{BROAD LEAVED BATAVIAN-The} leaves are large; heads well rounded; can be blanched; but generally used cooked like spinach or for flavoring soups and stews. Packet $5 c$; ounce $15 c$; 1/4-lb. 40c.

GREEN CURLED-Produces beautiful curled, tender, dark-green leaves; used largely for winter salad. Packet $5 c$; ounce $15 c$.

\section{Kohl Rabi}

Packet 5c; ounce 25c

EARLY WHITE VIENNA-Turnip-like bulb growing above ground, having a combination flavor of the turnip and cabbage.

PURPLE VIENNA-Same as above with the exception of the color.

\section{Kale}

DWARF CURLED-Finely curled and low growing; will stand freezing. Packet $5 c$; ounce $15 \mathrm{c} ; 1 / 4-1 b$. 50c.

TALL GREEN CURLED SCOTCHDark shade of green; leaves finely curled. This variety is fine for poultry as it will stand colder weather than the Thousand Head. Packet $5 c$; ounce $15 c$; 1/4-lb. $40 c$; 1-lb. $\$ 1.35$.

THOUSAND HEAD OR COW-This is a favorite as a green feeder for winter. Its enormous production qualities makes it popular both with the dairymen and chicken raisers. Packet $5 c$; ounce $10 c ; 1 / 4-1 b$. $20 \mathrm{c} ; 1-\mathrm{lb} .50 \mathrm{c}$.

\section{Leek}

LARGE ROUEN OR AMERICAN FLAG - Strong growing, broad leaved variety. Hardy and productive. Packet $5 c$; ounce 25c.

\section{Mustard}

Packet 5c; ounce 10c; 1/4-lb. 25c

SOUTHERN GIANT CURLED-Hardy; large, light green leaves, crimped and frilled at the edges.

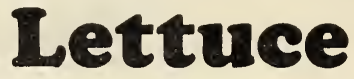

Packet 5c

HANSON HEAD-The old standard and popular sort; producing large firm heads of medium green color. Ounce $15 \mathrm{c} ; 1 / 1 / 1 \mathrm{lb}$. $35 c$.

NEW YORK, LOS ANGELES OR WONDERFUL-The most popular variety grown. It produces immense solid brittle heads of splendid flavor. Our strain has proved itself with the market gardener. Ounce 20c; $1 / 4-1 b$. 75c.

BLACK SEEDED SIMPSON-Makes large compact bunches of heavily crumpled leaves. Fine for feeding chickens. Ounce $15 \mathrm{c} ; 1 / 4-1 \mathrm{~b}$. $35 \mathrm{c}$.

GRAND RAPIDS-Loose leaf; very popular for green house forcing as well as out door planting. Crisp, compact bunches. Fine for poultry. Ounce $15 c ; 1 / 1-1 b$. 35c.

BIG BOSTON-Extra hardy and suitable for fall planting; plants large and leaves broad and edge tinged with brown. Ounce $15 \mathrm{c} ; 1 / 1-1 \mathrm{~b}$. $35 \mathrm{c}$.

EARLY PRIZEHEAD BROWN-Loose or non-heading variety with large browntinged leaves. Ounce $15 \mathrm{c} ; 1 / 4-1 \mathrm{~b} .35 \mathrm{c}$.

CHICKEN LETTUCE-This variety of lettuce is popular where a quick crop is wanted as it grows very rapidly and if not used at once soon becomes tough and seeds. Ounce $15 c ; 1 / 4-1 b .45 c$.

\section{Melons}

Packet 5c; Ounce 15c

IMPROVED ROCKY FORD MUSKFlesh thick, green, very sweet and highly flavored; very solid.

BURRELL'S GEMI-The flesh is reddish orange, very thick, fine grained and spicy.

SMALL GREEN NUTMEG, MUSKRipens early; flesh green, fine and sweet.

\section{WATERMELONS}

ICE CREAM-This is a round shaped melon. Flesh is pink and the quality the best. Matures early and is also a late keeper. Very prolific.

KLECKLEY'S SWEET WATERMELON -Very productive, medium size, oblong shape; flesh a beautiful rich red.

KLONDYKE-An exceptionally sweet melon and of the best quality. The fruit is oblong and the flesh is brittle. Excellent for both the home use and market.

TOM WATSON WATERMELON-Thin dark green rind; deep red flesh; crisp and sugary. 


\section{Onion Seed}

Packet 5; Ounce 15c; 1/4-lb. 50c; 1-lb. $\$ 1.90$

(except where noted)

AUSTRALIAN BROWN-A sure cropping variety with long keeping qualities; with crisp white flesh.

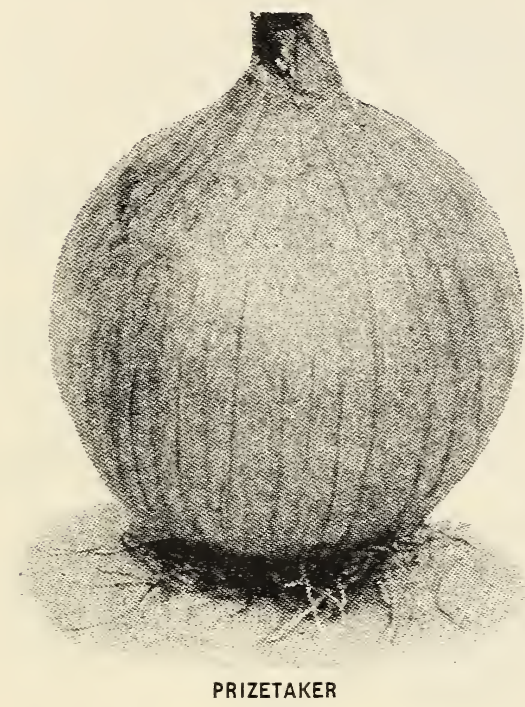

YELLOW GLOBE DANVERS-This onion is large, nearly globe-shaped with a small neck; early and a heavy yielder.

PRIZETAKER-Extra large onion of mild flavor; globe shaped with small neck; color bright straw.
RED WETHERSFIELD-Large flat onion, color purplish red.

SILVERSKIN OR WHITE PORTUGAL -medium early sort of good quality; flattened shape and clear white skin. Packet 5 c; ounce $20 \mathrm{c}$; 1/4-1b. $65 \mathrm{c}$; $1-1 \mathrm{lb}$. $\$ 2.50$.

QUEEN OR BARLETTA-If planted thickly produces small, very firm onions suitable for pickling. If given space will form a larger onion and is a good keeper. Packet $5 c$; ounce 25c; 1/4-1b. $85 c ; 1-1 b$. $\$ 3.00$.

SWEET SPANISH ONIONS-This is the genuine Sweet Spanish; a distinct globe-shaped type and often grows to weigh one to three pounds. To produce the large size they should be thinned to 6 to 8 inches between plants; uniform moisture should be kept. Packet $5 c$; ounce $35 c$; $1 / 4-1 b$. $\$ 1.15$.

\section{Onion Sets}

1-lb. 20c; 5-lbs. 90c.

YELLOW BOTTOMS-Will produce green onions in a very short time.

MULTIPLIERS OR SHALLOTS-Desirable for bunching. One set produces a cluster of medium size bulbs.

\section{PARSNIPS}

Packet 5c; ounce 10c; 1/4-lb. 25c; $1 / 2-\mathrm{lb} .40 \mathrm{c}$

IMPROVED GUERNSEY-The roots are large but not so long as other varieties; smooth, fine grained and of excellent quality.
HOLLOW CROWN-Very long, smooth, white and fine flavor and like other parsnips needs no protection in winter.

\section{PARSLEY}

Packet 5c; Ounce 10c

DARK MOSS CURLED-Used for flavoring and garnishing; bears a great number of fine curled leaves. 


\section{Garden Peas}

Packet 10c; 1/2-lb. 20c; 1-lb. 30c; 5-lbs. \$1.35; 10-lbs. \$2.50

(except where noted)

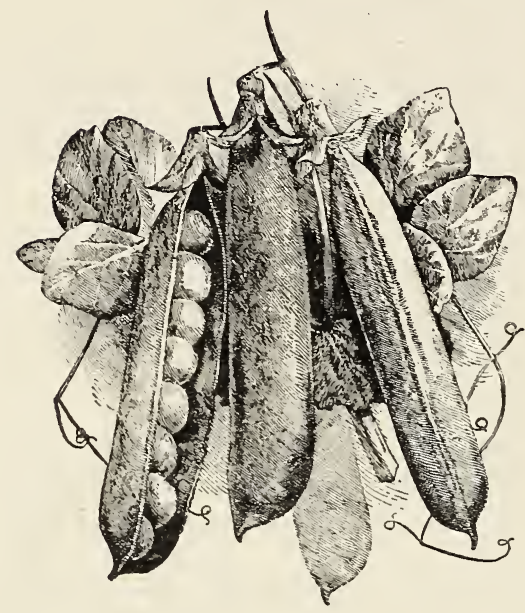

ALASKA-The earliest of all peas; round seeded and stand the wet cold soil better than the wrinkled sorts. Packet $10 \mathrm{c} ; 1 / 2-\mathrm{lb}$. $15 \mathrm{c} ; 1-\mathrm{lb}$. 25c.

AMERICAN WONDER-One of the earliest of the wrinkled peas; dwarf; pods and peas small.

WORLD'S RECORD-An improved Gradus; pods a little larger and darker green; height 2 feet; quality the very best. Early.

GRADUS-Large podded and sweet; one of the favorites of the early peas.

PREMIUM GEM-An early dwarf variety; vines average 15 inches high, well filled with pods.

LAXTONIAN-Also called Blue Bantam-enormous pods, well filled, on dwarf vines; peas extra sweet and dark green. Fine for home gardens.

THOS. LAXTON-Similar to the Gradus, only a few days later; yields a little heavier; rich sweet flavor.

DWARF TELEPHONE-Strong plants $2 \frac{1}{2}$ feet high; large, long pods containing dark green peas of finest quality. Late.

IMPROVED STRATEGEM - M edium vines producing large pods filled with large peas. A fine late variety.

TALL TELEPHONE-This is one of the best late croppers of the tall sorts; grows 4 to 6 feet tall; peas are large and fine for canning.

MELTING SUGAR (Edible Pod)-Prepare as snap beans; large broad pods, brittle and snap without leaving a string; fine flavored.

SWEDISH SUGAR OR SOUP PEAUsed same as Melting Sugar and it is also unexcelled as a dry pea for soup. Try them for winter use.

\section{PEPPERS}

Packet 5c; Ounce 60c

One ounce will produce about 1,000 plants

CULTURE-Peppers are more sensitive to frost than most vegetables, and they should not be planted out until settled warm weather has arrived. The seed should be sown in a hotbed, coldframe, or if no better convenience is available, a box in a window; transplant later into rows 20 inches apart each way, and keep the soil clean and well stirred.

CRIMSON GIANT-Extra large and $\diamond$ crimson when ripe-fine for stuffing.

LARGE BELL OR BULL NOSE-Fruit large, thick and mild; fine quality.
HARRIS EARLIEST-The earliest of the large varieties; it will mature ripe peppers two weeks earlier than the Chinese Giant. 


\section{PUMPKIN}

Packet 5c; ounce 10c; $1 / 4-\mathrm{lb}$. 30c

SMALL SUGAR OR SWEET PIERound small pumpkin; very fine flavored. Matures early and is fine for pies.

WINTER LUXURY - The meat is very thick, fine grained and of rich golden yellow: It is by far the best pumpkin and has no equal in quality, and is a good keeper.

CONNECTICUT FIELD-This is a common field pumpkin and is used mostly for stock feeding and jack o'lanterns, while some prefer it for pies.

\section{RADISHES}

Packet 5c; ounce 10c; 1/4-lb. 30c; 1-lb. $\$ 1.00$

EARLY SCARLET TURNIP WHITE TIPPED-This is the most popular of the early radishes; it matures early and the beautiful roots of bright scarlet are tipped with white.

FRENCH BREAKFAST-This is also an early sort; its form is oval, color bright scarlet, tipped with white.

CRIMSON GIANT-The largest of the turnip rooted radishes; very early and is slow in reaching the pithy stage.

CHINA ROSE WINTER-A winter variety; grows four or five inches long. The skin is bright rose; the flesh is white, crisp and solid.

HALF LONG DEEP SCARLET-A very fine variety; a little longer and larger than the French Breakfast; fine for forcing; flesh white.

MIPROVED CHARTIER-One of the most distinct of the long varieties; scarlet top and tipped with white; pleasant flavor.

WHITE ICICLE-This is the finest of the long white radishes; it retains its crispness longer than any other; tender, crisp and delicate flavor.

\section{SPINACH}

Packet 5c; ounce 10c; 1/4-lb. 20c; 1-lb. 50c

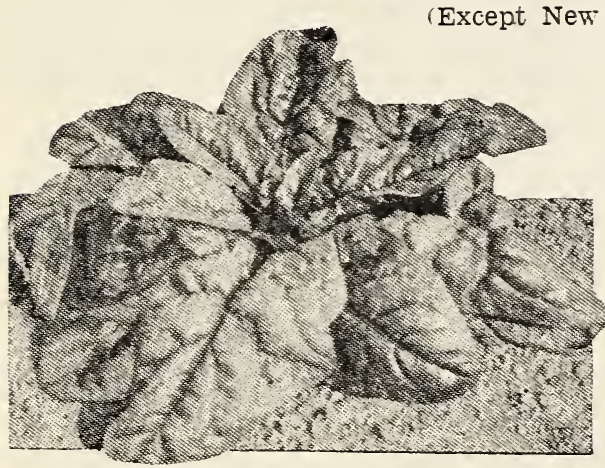

KING OF DENMARK-A wonderful new spinach; the leaves are crumpled and dark green. Does not run to seed as soon as other summer varieties.
IMPROVED THICK LEAVED-The leaves are broad and smooth and medium dark green color; stands the cold well.

BLOOMSDALE SAVOY LEAVED-Very early; of upright growth; leaves pointed. Grows quickly. Can also be planted in fall for spring use.

NEW ZEALAND-The abundant fresh tender leaves can be picked frequently; does well in the hot dry weather. Ounce $15 \mathrm{c} ; 1,2-1 \mathrm{~b}$. $35 \mathrm{c}$.

MAMMOTH WINTER OR PRICKLY WINTER-This has become very popular for a spring, summer and fall cutting; leaves large and fairly smooth and is slow to run to seed.

\section{Salsify}

MAMMOTH SANDWICH ISLAND-AIso known as Vegetable Oyster-Its flavor resembles that of the oyster. Cultivate as carrots or parsnips. Packet $5 \mathrm{c}$; ounce $15 \mathrm{c}$; $1 / 4-1 b .50 c$.

\section{Sunflower}

MAMMOTH RUSSIAN-A very heavy yielder and produces large heads; the seeds are fine for poultry and the whole plant is used largely for ensilage. Ounce $5 c ; 1 / 4-1 b .10 c ; 1-1 b .25 c ; 10$ lbs. at $15 c$ per lb. 


\section{Squash}

Packet 5c; ounce 15c; 1/4-lb. 35c $1 / 2$-lb. 60c 1-lb. $\$ 1.15$

DELICIOUS-Extra sweet, fine grained; top shaped with dark green skin; the flesh is thick. Try this fine squash.

BANANA-Grows from one to three feet in length owing to culture and soil. Color is a gray-green, of good quality and flavor.

G R E E HUBBARD-The standard squash and while we do not consider it equal to the Delicious in flavor, yet it is a heavier yielder and better known on the market.

G O L D E N H U B B A R D-Similar in size and shape to the Green Hubbard, but a golden-red color.

MARBLEHEAD-One of the old reliable sorts and still gaining in popularity. Light blue-gray in color and shape resembling the Hubbard. The flesh is rich yellow, dry, sweet and delicious in flavor. Very prolific. Packet $5 \mathrm{c}$; ounce $15 \mathrm{c}$; $1 / 4-\mathrm{lb}$. 45c.

TABLE QUEEN OR ACORN-A minature squash growing about 7 inches long; color deep green contrasted with orange and red where it rests on the ground; very sweet and fine grained. Packet $5 \mathrm{c}$;

\section{Summer Squash}

Packet $5 \mathrm{c}$; ounce $15 \mathrm{c} ; 1 / 4-\mathrm{lb}$. $45 \mathrm{c}$

WHITE BUSH SCALLOP-An early summer squash; white, flattened in shape; bush.

COCOZELLE OR ITALIAN MARROW -Dark green color; best when six to eight inches long.

VEGETABLE MARROW-Skin greenish yellow to creamy white; regarded as the best of all summer squashes.

MAMMOTH SUMMER CROOKNECK -Fine for summer use; very popular; should be eaten before full grown.

\section{Tomatoes}

Packet $5 \mathrm{c}$; ounce $30 \mathrm{c} ; 1 / 4-\mathrm{lb}$. $\$ 1.00$

BONNY BEST-Owing to its uniformity this tomato has become popular with packers and for home use; yields a heavy crop of bright scarlet tomatoes.

EARLIANA-A trifle earlier than the above variety but not so uniform in size; the next best variety for this locality.

BURBANK-Although new this variety is proving good; prolific, continuous bearer; peals easy and is wilt resistant; flesh is firm.
JOHN BAER-Produces solid, highcrown, brilliant red tomatoes. Ripen five to ten days earlier than the Earliana. Keeps well and a good shipper; prolific and a continous bearer. Resistant to wilt and other diseases. Packet $5 c$; ounce $30 c$; $1 / 4-1 b$. $\$ 1.00$.

HUSK TOMATO Or GROUND CHERRY-Will grow to perfection under ordinary conditions; yielding abundantly of small very sweet fruit closed in a husk or calyx. Packet 5c; ounce 50c.

SMALL PEAR-Produce their fruit in clusters; desirable for preserves and pickling. Can supply either in red or yellow.

\section{Turnips}

Packet 5c; Ounce 10c; 1/4-1b. 25c; 1-lb. 75c (except where noted)

EARLY MILAN-Among the earliest smooth, flat and good quality; best for early or late planting. Ounce $15 \mathrm{c} ; 1 / 4-1 \mathrm{~b}$. $30 \mathrm{c}$; $1-1 \mathrm{~b}$. $\$ 1.00$.

E A R L Y S N O W B ALL-Extra early round turnip, snow white, crisp and solid.

EARLY FLAT DUTCH-Can be sown either in drills or broadcast; form, flat; color, pure white.

PURPLE TOP WHITE GLÓBE-The best all around turnip for fall and winter use. Pure white, with purple top; smooth globe shape, fine sweet flavor and very productive.

WHITE EGG - Quick growing, eggshaped, smooth; flesh white; very sweet, firm and mild.

PURPLE TOP STRAP LEAVED-A general favorite; flat form with bright purple top; fine for table or stock feeding.

YELLOW ABERDEEN-Grown largely for stock feeding; flesh yellow and fine texture; good keeper.

\section{Rutabagas}

Packet 5c; ounce 10c; 1/4-lb. 25c; 1-lb. 75c

AMERICAN PURPLE TOP-This is the general variety of the country; color of flesh is yellow; top, purple. Almost free from side roots.

BANGHOLM-Roots are large, tankard in shape; and excellent sort for either table or stock.

WHITE RUSSIAN-Large pure white variety of irregular shape; solid keeper. flesh very sweet.

\section{Tobacco}

\section{Packet $5 \mathrm{c}$; ounce $50 \mathrm{c}$}

CONNECTICUT SEED LEAF-The earliest and best for the northwest; used both for smoking and insecticide. 


\section{HER B S}

5c per Packet

Dill

Rosemary

Horehound Sage

Lavender

Sweet Marjoram

Summer Savory

Thyme

\section{Vegetable Plants}

ASPARAGUS ROOTS-See Asparagus . page 2.

CABBAGE (Early Jersey Wakefield) $-15 \mathrm{c}$ per doz; \$1.00 per 100 .

CABBAGE (Late)-Late Flat Dutch, Danish Baldhead and Red Drumhead; $15 \mathrm{c}$ per doz; $\$ 1.00$ per 100 .

CAULIFLOWER-Early Snowball, 20c per doz; $\$ 1.25$ per 100 .
CELERY-White Plume and Golden Self-Blanching, 20c per doz; \$1.25 per 100.

KALE - Thousand Headed or Cow Kale and Tall Green Curled, 15c per doz; $\$ 1.00$ per 100.

TOMATO-Bonny Best and Earliana 40c per doz; \$2.50 per 100.

\section{Lawn Grasses}

All of our Lawn Mixtures contain Creeping Bent FANCY MIXTURE-A fine mixture
and gives good results; contains no noxious weed seed; per pound $45 \mathrm{c}$; 10-lbs. $\$ 4.00$. Over four pounds at 10 pound rate.

"LAWNGREEN"-This is one of the best lawn grasses on the market for the price and will make a green velvety lawn in a shorter time than anything we have tried. 60c per pound; 10-1bs. \$5.50.

"OUR SPECIAL"-This mixture is equal to any Dollar lawn grass on the market and you will be pleased with the results obtained. Use this when you want extra results; $75 \mathrm{c}$ per pound; 10 -lbs. $\$ 6.75$.

"PUGET SOUND BENT MIXTURE"This mixture is a blend of Creeping Bent and other fine grasses which produce a beautiful velvety green lawn. This mixture is unsurpassed for the surrounding of a fine home. Price per pound $\$ 1.00 ; 10$ lbs. 9.00 .

\section{NOTE}

There are many causes that keep seed from coming up. This may be due to some of the following reasons: Covering too deep or not deep enough, too much or not enough moisture, ground too cold or the surface of the ground baked by the hot sun. Under these conditions we can give no warranty, expressed or implied, as to the description, quality, productiveness or any other matter of any seeds or plants that we have sent out, and will not be in any way responsible for the crop. If the purchaser does not accept the goods on these terms, they must be returned at once. 


\section{Flower Plants}

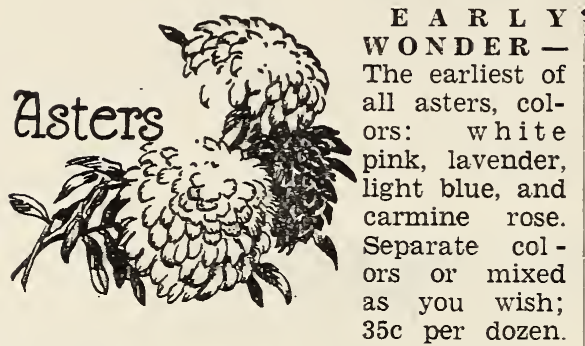

CALIFORNIA GIANTS-Largest and most satisfactory for later planting; colors: white, pink, light blue, lavender, rose and purple. Separate colors or mixed as you wish; 35c per dozen.

BABY BREATH-Perennial, 20c each; two roots for $35 \mathrm{c}$.

C O L U M B I N E-Long-spurred; mixed colors; 10c each.

COSMOS-Early flowering, single or new double crested; 50c per dozen.

DELPHINIUM-Perennial, 20c each.
GERANIUMS-Red, pink and white, 20c each; three for 50c; $\$ 2.00$ dozen.

GEUM (Perennial)-Mrs. Bradshaw, red; Lady Stratheden, yellow; 25c each; $\$ 2.50$ doz.

MARIGOLDS-Tall African, 40c per dozen.

OR I EN TA L POPPIES-Should be planted in the fall for the best results; can supply plants now, 20c each.

PANSY PLANTS-Mastadon, 50c per dozen.

SNAPDRAGON-Annual 50c per dozen. SALVIA-America. 50c per dozen.

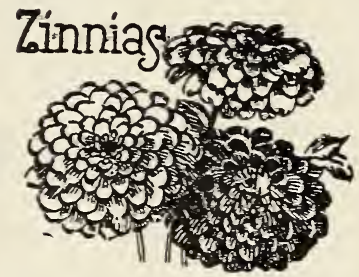

Annual - Bodg ers Gold Medal D a hlia Flowered, separate colors or $m$ ixed, (s e e Zinnia seed page 22), 50c per dozen.

All of our plants are grown in the open ground or cold frames as they stand the transplanting and make hardier plants than those grown in greenhouses.

(Order early as the perennials start growing early in the season)

We have combined quality of seeds with the price so that they will be within the reach of every home gardener but the quality is above everything else.

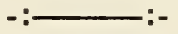

We specialize in high grade seeds that interest the Market Gardeners. They will also interest you. If you have not tried ours send us a trial order and we will be interested in your inquiries.

If interested in Dahlia Values look up our collections, especially Collection 38 Our Dahlia Collections are worth your while; read them over 


\section{Sweet Peas}

There are several hundred varieties of Spencer Sweet Peas, many of them of splendid merit, but in many cases the varieties are much alike. Those listed below are of the mast distinct and highly recommended in the Burpee and Bodger Strains.

CULTURE-It is a well known fact that, in ordel to have the largest blooms of Sweet Peas, seed must be planted early so as to make the greatest root development during early spring. Sow seed as soon as the ground can be worked. Dig a trench a foot wide and deep and fill in with 6 inches of well-rotted stable manure; tread down firmly and fill in with good garden soil; plant seed in a straight line along the prepared surface, about 3-4 inch deep and about 3 inches apart. When plants are three or four inches high thin out to six inches apart. Experts who raise for exhibition thin out to one foot. Keep well watered.

The following kinds are 10c per packet; 6 packets for 50c

in separate colors. per ounce $25 \mathrm{c}$

For 1929 Novelties in Sweet Peas see Page 1

\section{WHITE}

CONSTANCE HINTON-One of the largest and best whites.

KING WHITE-The finest pure glistening white.

\section{CREAM}

DOB BIE'S CREAM-Deep cream; splendid size and long stems.

\section{CREAMI PINK}

MARY PICKFORD-Flowers on long stem of dainty cream-pink suffused with salmon.

PICTURE-Cream and pink shades blended; considered the largest sweet pea.

CA R E S S-A soft pink on a cream ground; dellcate.

IMPROVED MARGARET ATLEERich glowing pink on cream ground; large.

\section{DEEP PINK}

COUNTESS SPENCER-An old favorite; a fine bright pink.

\section{ROSE PINK}

GEORGE HERBERT-The blooms are a rich, rosy carmine; large and waved.

\section{SALMON}

BARBARA-Rich glowing salmon; the finest in this shade.

\section{CERISE}

DORIS-A soft salmon-cerise; abundance of flowers.

ILIUMINATOR-Salmon-cerise; a rich wonderful combination.

\section{LAVENDER}

ASTA OHN-Large waved flower of lavender suffused with mauve.

FLORENCE NIGHTINGALE-Soft rich lavender enlivened with a faint sheen of rosy pink.

ORCHID-One of the best lavenders; extra large flowers.

\section{CRIMSON}

CRIMSON KING-Giant flowers of rich deep crimson.

KING EDWARD-Crimson self; flower large.

\section{SCARLET}

THE PRESIDENT-A brilliant orangescarlet self; four-flowered sprays.

SCARLET EMPEROR-Brilliant scarlet; large size flowers.

\section{ORANGE}

TANGERINE-This sort is well-named; a deep orange. Flowers well waved and of large size.

HELEN LEWIS-Wings, orange-rose; standards rich crimson-orange.

\section{MAROON}

KING MANUEL-Large, full, wavy blooms; deep brilliant maroon.

\section{PURPLE}

ROYAL PURPLE-A rich, warm purple; a rare shade.

\section{BLUES}

MRS. TOM JONES-Flower is large, brighter than Wedgewood; a uniform delphinium blue.

NEW WEDGEWOOD-A true self; beautiful blue; large and vigorous.

COMMANDER GODSHALL-Attractive shade of deep violet blue; waved and fluted.

\section{MIXED SPENCERS}

SUPERIOR MIXTURES-All colors; packet $10 \mathrm{c}$; ounce $20 \mathrm{c}$.

EXTRA CHOICE MIXED-An extra fine mixture. Packet 10c; ounce 25c.

\section{GRANDIFLORA MIXED}

GRANDIFLORA MIXED-All colors. Packet $5 c$; ounce $10 c ; 1 / 4-1 b .25 c$. 


\section{". Flower Seeds}

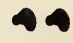

ASTERS-Early Wonder. This new creation is the earliest blooming aster; flowers are large and full, of the Comet

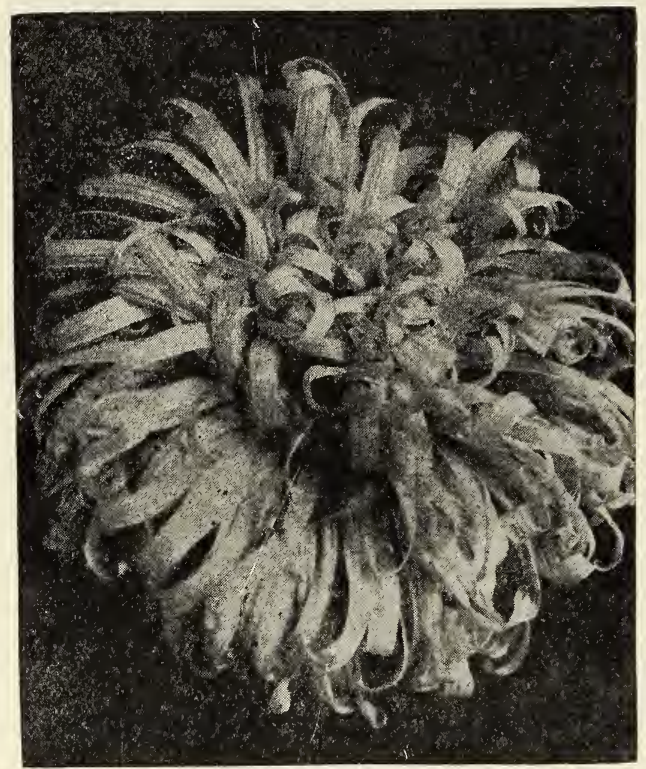

IMPROVED CREGO

type. Colors: white, packet 10c; light rose, packet 10c; light blue, packet 10c; lavender, packet 10c; carmine rose, packet 10c; mixed packet 10c: one packet each, (6 in all) $50 \mathrm{c}$.

ASTER-"Heart of France." This is one of the most beautiful shades of red aster yet produced. Stems long and strong; fine for cutting. Per packet 10c.

ASTER-"Sensation." This is a rich ox blood color which glistens in the sun. Early bloomer; semi-dwarf habit; excellent for borders. Per packet 10c.

ASTER-"Lavender Gem." Plants about 18 inches tall; upright habit. Comet type. Color, silvery white when young, changing to light lavender when fully expanded. Packet 10c.
ASTER-"New Fancy Yellow." This is by far the best yellow grown; it is fairly large and fully double. Packet 10c.

ASTERS-Mixed-Vicks earliest. A very fine mixture of all colors; producing flowers of immense size. $\mathrm{Pa}$ cket $5 \mathrm{c}$.

ASTER-“California Giant."-A giant new class; strong vigorous habits with the Crego type of bloom. The flowers are often 5 and 6 inches in diameter. Colors: peach blossom, packet 10c; light blue, packet 10c; light purple, packet 10c; deep rose, packet 10c; white, packet 10c; dark purple, packet 10c; mixed, packet 10c. One each of above $55 \mathrm{c}$.

ASTERS-Improved Crego. Vigorous plants producing large fluffy blooms on good stems. White, packet 10c; Shell pink, packet 10c; crimson, packet 10c; lavender, deep rose, packet 10c; purple, packet 10c; mixed packet 10c. One packet each of above 55c.

ARBIS (Rock Cress)-Hardy perennial producing a mass of blooms in the spring. Fine for borders and rock work. Packet $5 c$.

ACROCLINIUM-A hardy annual. Everlasting. Flowers white or rosy-pink. Cut while in the bud state and dry for winter bouquets. Sow early and transplant. Packet $5 c$.

AFRICAN DAISY, HYBRID-These hybrids of the Golden African daisy are indeed magnificent in every way. The combination of colors is most varied; some are self colored. Blooms measure about $2 \frac{1}{2}$ inches in diameter and they have a fine silky gloss. Packet $5 \mathrm{c}$.

SWEET ALYSSUM-Annual, used extensively for borders and is valuable for cutting; delightfully fragrant. Packet 5c. 
ALYSSUM, PERENNIAL-"Basket of . Gold." Hardy; 6 to 12 inches high. Produces a mass of golden yellow flowers early. One of the best rock plants and good for borders. Effective with Arbis. Packet 5c.

ACHILLEA-(Ak-i-lea-a), grows easily from seed and should be started inside for early blooms; responds to good soil and plenty of water. A profusion of double white flowers. Packet 10c.

ACONITUM-(Ak-0-ni-tum), "Monks Hood" perennial, blooms in August and September. One of the finest blues in the hardy border; best in masses with shrubs. Packet 10c.

ANCHUSA (An-ku-sa), perennial; is becoming a great favorite in hardy gardens; blooms May to July; best grown in groups; clip faded flowers to prolong blooms. Finest blue spikes. Packet 10c.

ANEMONE (A-nem'-o-ne), hardy per ennial. They make a beautiful display when planted in beds or borders and are excellent for bouquets and table decorations; one of the earliest of the spring flowers. Packet 10c.

ANTIRHINUM ("Snapdragon")-One of the best hardy annuals; will stand mild winters and bloom in early spring.

FIRE KING-Orange scarlet, packet $10 \mathrm{c}$.

GOLDEN KING-Giant yellow, packet 10c.

QUEEN VICTORIA-Pure white, packet 10 .

ROSE QUEEN-Soft pink, packet 10c.

NELROSE-deep rose pink, packet 10c.

MIXED, packet 5c.

One packet each $45 \mathrm{c}$.

BABY BREATH-See Gypsophelia.

BACHELOR'S BUTTON-A hardy annual, easily cultivated. Produces flowers of great variety of colors on tall branching stems with little foliage. Sow in open ground; easily transplanted. Per packet $5 c$.

BEANS, SCARLET RUNNER-Favorite English climbing bean, bright scarlet blossom and ornamental. Packet 5c; large package $10 \mathrm{c}$.

BLUE LACE FLOWER-Most beautiful shade of sky-blue, with clusters of flowers on long graceful stems; fine for cutting. Packet $5 c$.
BOLTONIA (bol-to'-ni-a - perennial; blooms July through September; large flower heads like single Asters. Group with perennial aster for combination in fall garden. White and pink. Packet 10c.

B R A C H Y COME - (Brak-i-ko'-me) "Swan River Daisy," free flowering annual; covered in summer with small white and blue flowers. Packet 5c.

BROWALLIA-(bro-wal'-i-a) Amethyst Annual, height 18 inches. One of the best blooming bedding plants. Packet $5 \mathrm{c}$.

CALENDULA (Pot Marigold) - An easy growing annual, blooming from early summer to late in fall. Requires little attention and will respond to watering in the dry season. Packet 5c.

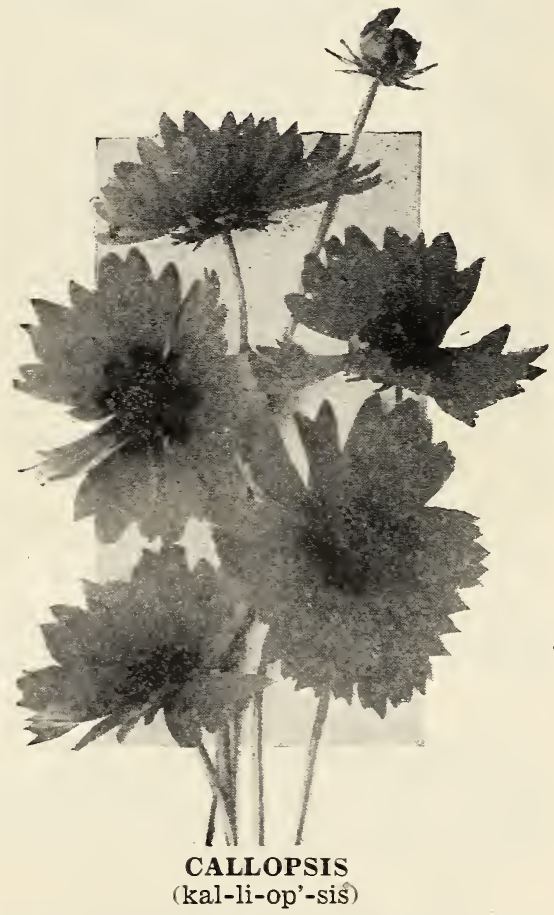

Showy and beautiful flowering annual of easy culture; blooms all summer; fine for cutting and massing. Yellow. Packet $5 c$.

CANDYTUFT-A favorite for bedding or borders. Can supply in plain white or mixed. Packet 5c.

CANARY BIRD VINE-A rapid-growing, tall climbing annual, producing hundreds of fringed bright yellow flowers. Packet 5c. 


\section{FLOWERS (Comtinued)}

CANTERBERRY B E L L S-Beautiful hardy, herbaceous perennial, bearing a great profusion of attractive bellflowers; thrives best in light soil. Packet 5c.

CARDINAL CLIMBER-A rapid growing annual climber. Fiery scarlet, tubular flower, dense green foliage. Packet 5c.

CARNATION-A perennial blooming the first season; generally desired for the delicious fragrance and bright colors. $\mathrm{Pa}-$ cket 5c.

CASTOR OIL BEAN-Annual decorative plant with palm-like foliage; gives the garden a sub-tropical appearance. Packet $5 c$.

C H RYS A NT H E M U M-Annual (see Painted Daisy). Packet 5c.

CLARKIA-A handsome annual which should be more widely known; easily grown; graceful habits and fine for bedding and cutting. Mixed. Packet 5c.

COREOPSIS-Similar to Calliopsis in habit of growth but is perennial; for cut flowers it stands near the head of the list. Easily grown from seed. Packet 5c.

COLUMIBINE-Aquilegia, long-spurred, mixed, perennial. Grouping with Clarkia, Annual Larkspur, Salpiglossis and Schizanthus gives a most effective combination; mixed colors. Packet 10c.

COCKSCOMBE-Free blooming annual; grows best in light soil; also attractive in pots. Mixed colors. Packet 5c.

COSMOS-Early Mammoth flowering, beautiful autumn blooming annual; makes a very graceful cut flower. Mixed. Colors: pink, red and white. Packet 5c.

COSMOS-New extra early "crested" or double flowering Cosmos; planted late in April will bloom in July; about 75 per sent of blooms come double. Colors, pink, red and white. Packet 10c.

CXPRESS VINE-A most beautiful, rapid-growing climbing vine, with dark green, delicate fern-like foliage and an abundance of bright, star-shaped flowers. Soak seed a few hours before planting. Packet 5c.

DAHLIA-Growing Dahlias from seed is very interesting. Start plants early and transplant about May 1st. This mixture contains many colors in different types. Packet $10 \mathrm{c}$.

DAISY (English Daisy)-Bellis, finest mixed, perennial. Sow in boxes in August and transplant to cold frames for protection for the first winter. Plant in permanent location in early spring. Packet $10 \mathrm{c}$.

DELPHIN I U M -Perennial Larkspur. Plant Delphinium in groups before a green background; shrubbery, a vine-covered wall or fence or lattice; combines charmingly with the blue Delphinium. Packet 5c.

DATURA (da-tu'-ra) - "Angels Trumpet.". Hardy annual, a very handsome, large showy plant, having large trumpet-shaped, fragrant flowers. Prefer light soil and sunny sheltered situation. Packet $5 c$.

ECHINOPS (e-chi'-nops)-Globe Thistle. Striking hardy perennial, with handsome, silvery, thistle-like foliage; fine steel-blue flowers in round heads. Height 3 to 5 feet. Packet $5 \mathrm{c}$.

EVERLASTING-A choice mixture of different varieties including Helichrysum, Statice, Acroclinium, Rhodanthe and Xeranthemum. Packet 5c.

FORGET-ME-NOT-Few spring flow ers are more admired; effective for mass planting; with the ferns in the shaded nooks. Packet 5c.

FOX GLOVE-One of the finest perennials bearing long spikes of tubular flowers. Plants will grow in partial shade and in almost any soil. Packet 5c.

GUEM (Mrs. Bradshaw)-Perennial with semi-double flower about two inches in diameter; flowers borne on long stems; fine for cutting. Brilliant scarlet. Packet 10c.

\section{Collection of Everlastings}

This assortment contains one packet each of the following six varieties: Acroclinium Globe, Amaranth, Helichrysum, Rhodanthe, Statice and Xeranthemum; also one packet of perennial Baby Breath which are fine when cut and dried for winter bouquets. 7 packets in all for 20c. Great value! 
GUEM (Lady Strathden)-Same as . above; flowers large double. Yellow. Packet $15 \mathrm{c}$.

GODETIA-Hardy, pretty annual suitable for beds, borders and to grow in shady places; grown rapidly; blooms early and until frost. Mixed. Packet 5c.

G L O B E A M A RANTH-Gomphrena mixed. The blooms closely resemble the clover blossom. The mixture includes a fine range of colors. When grown the plants are about two feet tall and are literally covered with blooms. Packet 5c. Everlasting.

GLOBE AMARANTH-See Everlasting.

GYPSOPHILA (jip-sof'-i-la)-“Baby's Breath." Annual; producing graceful flowers in abundance in loose panicals. Has a delicate effect in bouquets.

GYPSOPHILA-Perennial. Makes fine clumps for garden use. Cuttings used as an everlasting for winter decorations. Packet 5c.

GOURDS-Annual. Quick growing vine excellent for covering arbors, walls and waste places; all shapes. Packet 5c.

HELIOTROPE-Annual. Fine for bedding; very fragrant. Graceful in habit of growth and valuable for cutting. Start indoors and plant out in May. Packet 10c.

HELICHRYSUM (he-li-kri-sum)-Annual. Mixed. Everlasting, one of the best flowers to try for house decoration; gather before blooms expand and hang heads downward. Packet 5c.

\section{HELICHRYSUM-See Everlasting.}

HOLLYHOCK-Perennial, double. Mixed colors. Excellent for rows in garden or for background of buildings or high walls; need rich soil and plenty of water; cultivate well. Packet 5c.

HIBISCUS (hi-bis'-kus) - "Marshmallow". Perennial. Showy ornamental plant that blooms from August to October, for mixed beds or shrubbery; flowers the first year if planted early. Packet 10c.

LUPIN-Same as above, only perennial. Packet 5c.

L A R K S P U R -Annual. Plant little groups in garden; 8 to 12 inches according to richness of soil; makes attractive spots of color through summer and fall. Packet 5c.

LUPINE-Annual, mixed. Easily grown; long spikes of pea-like flowers of various colors; keep flowers cut and more will develop. Packet 5c.
LINUM (li-num)-Scarlet Flax. One of the most effective, and showy hardy annuals; having fine foliage and delicate stems; scarlet crimson flowers Height 1 foot. Packet $5 \mathrm{c}$.

LOBELIA-Dwarf. Best dark blue. Fine as a border plant; drawf and compact in habit. grows quickly. Packet 10c.

LOBELIA, TRAILING-This variety is much used for porch boxes, baskets and pots, owing to its delicate trailing habits. Packet 10c.

LYCHNIS (lik'-nis) - Handsome hardy perennial of easy culture, for massing in beds or for borders; blooms first year if seed are sown early, packet 5c.

MARIGOLDS-African, double flowered; hardy annual; 2 to 3 feet in height; either in the lemon or orange ball or mixed; blooms all summer and fall. Packet $5 c$.

MARIGOLDS-Annual,.. double French mixed; few annuals are as effective and bloom as long as the French Marigold. Packet 5c.

MARIGOLD-Legion or Honor. A fine single variety forming compact bushes about nine inches high. Begins flowering early and continues until frost. Flowers are bright yellow marked with velvety red spots. Packet $5 \mathrm{c}$.

MEXICAN FIRE BUSH (Kochia)-Popular ornamental annual, also known as Summer Cypress; fine for backgrounds, borders and hedges; turns fiery red in fall. Packet $5 \mathrm{c}$.

MIGNONETTE-Well known hardy little annual; sweet scented and at home anywhere. Packet 5c.

MORNING GLORY (Convolvulus) -A very popular annual as they are one of the most free-blooming and rapid growing plants in cultivation; often growing 15 feet in a season. Soak seed in warm water for one hour. Packet $5 c$.

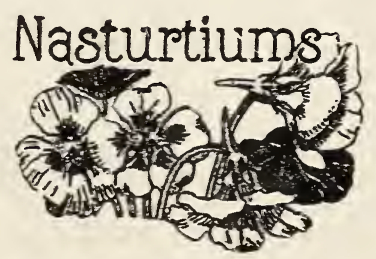

NASTURTIUM-Tall. Luxurious climbing variety for verandas, trellises, etc.; also covering for unsightly places. Packet $5 c$; ounce 10c; 3 ounces 25c. 


\section{FLOWERS (Continued)}

NASTURTIUM-Dwarf. Our nasturtiums contain a large variety of colors. A row of these in the garden or along the walk will produce a gorgeous effect Packet $5 \mathrm{c}$; ounce $10 \mathrm{c} ; 3$ ounces $25 \mathrm{c}$.

N E M O PHILA (ne-mof'-i-la)-Baby's Eyes." Hardy annual, 6 inches in height; excellent for borders and pots; flowers delicate blue and white. Packet 5c.

NICOTIANA (ni-ko-shi-a'-na). Half hardy annual. A handsome bedding plant, bushy habit and literally ablaze with sweetly fragrant blooms. Thrives best in sunny location. Packet 5c.

NIGELLA-(Love-in-a-Mist), A hardy annual, one foot high with finely cut foliage, oddly shaped blossoms in blue and white. Packet $5 \mathrm{c}$.

PAINTED DAISY-Annual Chrysanthemum. Plants average 2 feet, and bear daisy-like flowers in great profusion on strong stem. Packet 5c.

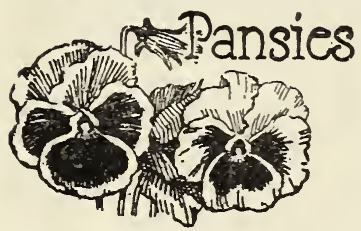

Mixed, Giant frilled, G iant flowering Mastadon. A grand mixture of the finest varieties. Packet 10c.

PETUNIA-Hybrid mixed; easily grown and bloom profusely until frost; no bedding plant makes a more pleasing effect. Packet 5c.

PETUNIA-Rosy Morn. A most pleasing clear pink, contrasted by a broad white throat. Single. Flowers until after frost. Packet 10c.

PETUNIA-Giant of California. This grand ruffled or fringed variety often measures 4 to 5 inches. The great variety of colors, blockings, stripings and veinings makes a fantastic and beautiful combination. Packet 20c.

PETUNIA-Double. The flowers are very large, full and symetrically formed; the edges of the petals are beautifully fringed; mixed. Pa.cket 35c.

PENTSTEMON (pen-ste'-mon)-Perennial. An ornamental plant which will flower the first year if sown early. The half pendent bell-shaped flowers show beautifuf shades and marking of scarlet pink, white and blue. Packet 10c.

PHLOX-A beautiful annual that may be used for massing, beds, borders or pots. Sow in open after danger of frosts. Special mixed. Packet 5c.
STAR PHLOX-Same as above except the flowers are Star shaped. Packet 5c.

...PINKS (Dianthus)-Double annual or biennial but treated as annual as the new plants produce a finer bloom and the older ones blossom earlier. Packet $5 c$.

PLATYCODON (plat-i-ko'-don-One of the best perennials, producing showy flowers during the whole season; forms large clumps and will bloom in August if seed are planted in April. Also known as Japanese Bellflower. Packet 10c.

PORTULACA-Sun Plant. It revels in the full sun and does not seem to heed the lack of moisture; used for narrow borders, rockeries and tops of retaining walls. Packet 5c.

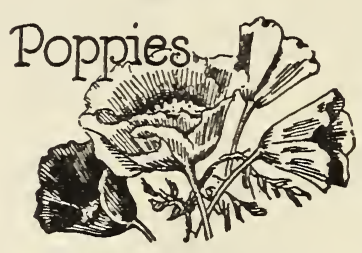

American Legion, $\mathrm{G}$ ia $\mathrm{nt}$ dazzling, orange or scarlet flowers on stout stems. Packet 5c.

POPPIES-California Poppy. Valuable for growing in beds or massing. Sow seed where plants are to be grown. A fine mixture of many different colors. Packet $5 c$.

POPPIES-Shirley. Annual. Containing a fine mixture from the lightest shades to almost blood red. Packet 5c.

POPPIES-Oriental, perennial; easily grown from seed and make a gorgeous display when in bloom; very hardy and fine for cut flowers; crimson. Packet $5 \mathrm{c}$.

POPPIES-Iceland, perennial; a bright green fern-like foliage, formed in tufts, from which slender flower stems protrude. Packet 5c.

POPPIES-Double annual variety. Large showy double globular flower. Beautifully fringed; orange, white and yellow. Packet 5c.

PYRETHRUM-Hardy perennial bearing daisy-like flowers in shades of pink, red and white; large flowering and fine for cutting. Packe ${ }^{+}$10c.

RHODANTHE-Everlasting-It is easy to grow and does particularly well in loose sandy soil. Sends forth a wreath of blooms in midsummer; white, shades of pink and red. Packet 5c.

RUDBECKIA (rud-bek'-i-a)-Golden Glow hardy perennial of easy culture. Flowers are quite double. Packet $5 c$. 


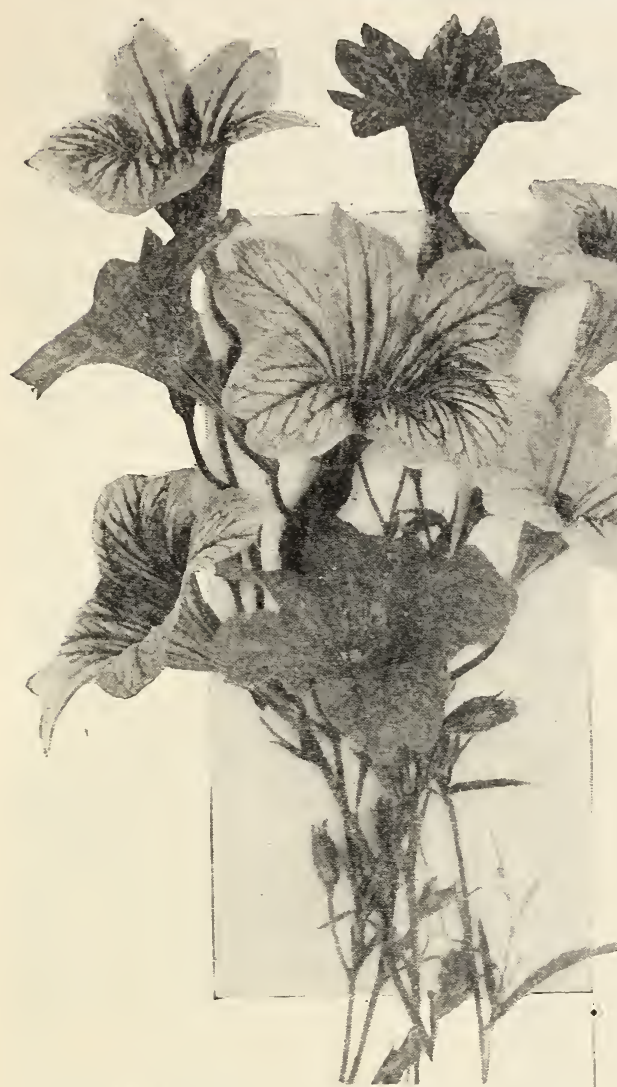

SALPIGLOSSIS (sal-pi-glos'-is)-Annual. The plants are branching and the slender stems are delicate; flowers trumpet shaped, beautifully veined and of most exquisite colors. It is almost a hopeless task to attempt a description of this flower. Packet 5c.

SALVIA (Scarlet Sage)-Annual. Sow indoors in March and plant out in May. Very ormatmental; flowers borne in spikes of fiery red or crimson. Packet 5c.

S C A B I OSA (ska-bi-o'-sa)-Morning Bride. The flowers are borne on long wiry stems; keep the seed pods clipped and it will bloom for a long seaon; mixed. Packet $5 c$.

SCHIZANTHUS (ski-zan'-thus)-Butterfly Flower. Low growing, delicately branching and covered with butterfly-like flowers. Packet 5c.
STATICE (stat'-i-ce)- Annual Everlasting; very attractive for bouquets and to $\mathrm{mix}$ with other straw flowers; Cluster of small flowers on a stem. Mixed. Packet $5 c$.

S T O C K S-Nice, annual mixed. These popular flowers are easily grown, are so highly fragrant and of such great beauty. They have so many good qualities that they deserve a place in every garden. Brilliantm ixture. Packet $5 c$.

STOCKS, Evening Scented-No annual in cultivation equals this in the delicate perfume of its flowers. The pink and lilac blossoms partly close during the day but expand and impart their fragrance during the evening. Packet 10c.

SHASTA DAISY - A popular evergreen perennial with single flowers, often five inches across. Purest glistening white. Packet 5c.

S N A P D R G O N-(See Antirrhinum, page 19).

SMULAX-Annual. One of the most beautiful useful climbers; fine for the green house or conservatory. Packet 5c.

STOKESIA (sto-ke'-si-a)-This is a rare and beautiful hardy perennial; plants 2 feet high; bearing 20 to 30 handsome lavender-blue cornflower-like flowers. $\mathrm{Pa}$ cket $5 \mathrm{c}$.

SWEET SULTAN-Beautiful, deliciously sweet-scented flowers borne on long strong stems; lasting well after cutting. Mixed. Packet 5c.

SWEET WILLIAM-Hardy biennial; 2 feet high. This sturdy, old fashioned favorite is still a source of delight in every garden today; fine mixed. Packet $5 c$.

VERBENA-Annual. Large clusters of showy flowers; borne in succession until frost; of trailing habit; foliage makes a perfect carpet. Packet 5c.

WALL FLOWER-One of the old favorites; they are very fragrant and of a special value as a cut flower. Give a sheltered location. Packet 5c.

We guarantee the safe arrival of your seed and guarantee their quality to the full amount of the purchase price. 


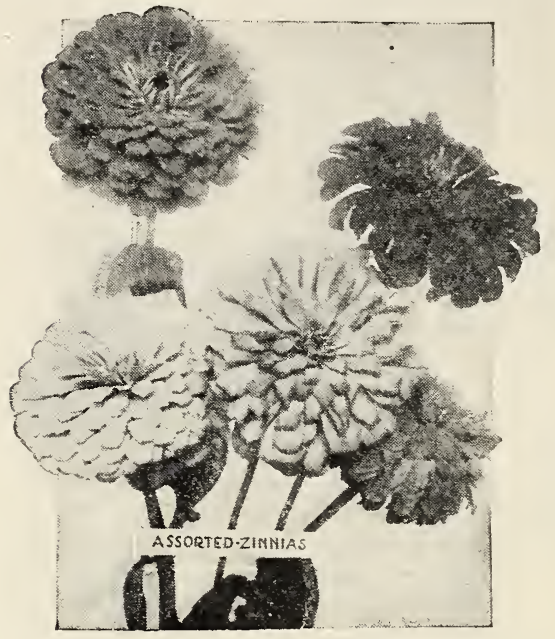

WILD CUCUMBERS-A fast-growing climber; often growing 30 feet in a season; white, fragrant flowers; prickly seed pods. Packet 5c.

ZINNIAS-Annual easily grown and has a long period of blooming; lasts well as a cut flower; thrives well in this climate. Mixed colors. Packet $5 \mathrm{c}$.

ZINNIA-Bodger's Gold Medal Dahlia Flowered. We used this variety last season in our plant department and feel safe in offering them again this season both as seed and plants. Color: Polar Bear, Crimson Monarch, Dream, Oriole and Exquisite and mixed. Packet 10c.

GOLD MEDAL-One packet each of the separate colors, (5 in all), 40c.

XERANTHEMUM-A charming everlasting with flowers measuring $11 / 4$ inches in diameter. About 2 feet tall and the plant bears a profusion of blooms until frost. Packet 5c.

\section{PERIOD OF GERMINATION FOR FLOWER SEEDS}

Achillea

No. of Days

Aconitum

.10 to 15

Acroclinum

180

African Daisy

12

Ageratum

Alyssum

5 to 10

Anchusa

5 to 8

Anemone 30

Antirrhinum

20 to 60

Aquilegia

8 to 12

Aster

12 to 60

Boltonia

5 to 10

Brachycome

Browallia

Bachelor Button

Calendula

8 to 10

Calliopsis

5 to 10

Canary Bird

8 to 10

Candytuft

Carnation

5 to 10

Cockscomb

10 to 15

8 to 10

Clarkia

Coreopsis

5 to 10

Cosmos

8 to 10

Cypress Vine

10 to 20

Castor Oil Eean

12 to 15

Dahlia

10 to 20

Daisy

8 to 10

Datura

15 to 20

Delphinium

20

Forget-me-not

Geum

15 to 60

Godetia

6 to 10

Gourds

.12 to 15

Gypsophila (annual)

Gypsophila (perennial)

Heliotrope

No. of Days

Hibiscus

Hollyhock

5 to 7

Larkspur

10 to 30

Lavender

Linum

Lobelia

Lupins

Kochia

10 to 15

Lichins

5 to 20

Marigolds

5 to 10

Mignonette

10 to 15

Nasturtium

5 to 10

Nicotinana

8 to 10

Pansy

8 to 10

Painted Daisy

8 to 10

Penstemon

8 to 10

Petunia

8 to 15

Phlox

8 to 10

Platycodon

8 to 10

Poppy

12 to 15

Poppy

Poppy (Oriental)

6 to 10

Poppy (Iceland) ............................... 15

Portulaca ….............................................. 10

Rudbeckia .......................................... 8 to 10

Salpiglossis ........................................ 5 to 10

Salvia ............................................... 5 to 10

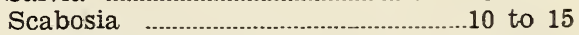

Schizanthus …................................... 5 to 10

Shasta Daisy ...................................... 20

Statice …......................................... 3 to 10

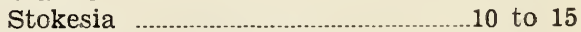

Verbena ............................................ to 15

Wallflower .................................. 5 to 10

Helichrysum

5 to 10 . Zinnias

10 to 20

5 to 10 


\section{Gladiolus Bulbs}

Few summer-flowering bulb plants have met with the same increased interest that the Gladioli have in the past few years. For either cut-flower or garden decoration during the summer and autumn months, they are not surpassed by any other bulbous plant we known of. In cutting Gladioli for the house it is best to cut the spikes as soon as one or two flowers open; the remainder will open in the house. Remove withered blooms, cut off a little of the stem and change water daily. When cutting leave four or five leaves on old stock.

Gladioli may be planted, at intervals of two weeks, from early spring until Iuly. Bulbs may be planted from three and a half to four inches deep in mellow soil anc from four to eight inches in the row.

We are offering this year the New and Marvelous Gladioli in the LACINIATED type and we feel that we are placing before our trade the Top Notchers in the glads.

COMET - A deep golden yellow Laciniated variety with large, red throat blotches. A very rich, deep yellow of pleasing appearance. $50 \mathrm{c}$ each.

LAVENDER BEAUTY-Pinkish lavender, flaked with deeper lavender. Lower petals a little lighter in throat with slight throat markings and narrow central lines. $75 \mathrm{c}$ each.

LACINATUS-The forerunner of the Laciniated race of gladioli. Beautiful rose pink and under good cuiture will reach $3 \frac{1}{2}$ to 4 inches in diameter. A large size bulb will produce four or five spikes of blooms. 30c each.

\section{COLLECTION NO. 20}

One bulb each of the Laciniated Type of glads; Comet, Lavender Beauty and Lacinatus, regular price $\$ 1.55$, all three for $\$ 1.40$.

\section{Ruffled Varieties}

ALTON-A wonderful ruffled variety of finest orange color. A magnificent Glad. $10 \mathrm{c}$ each; 1.00 dozen.

ANTHONY B. KUNDRED-Tall large, intensely ruffled nower of delicate, deep cream color; overspread finest blush-pink. Low petals, beautiful primrose cream flushed pink at edge. $20 \mathrm{c}$ each; $\$ 2.00 \mathrm{doz}-$ en.

AVALON-Extra choice blush white; very beautiful throat. Artistic and beautiful. $15 \mathrm{c}$ each; $\$ 1.50$ dozen.

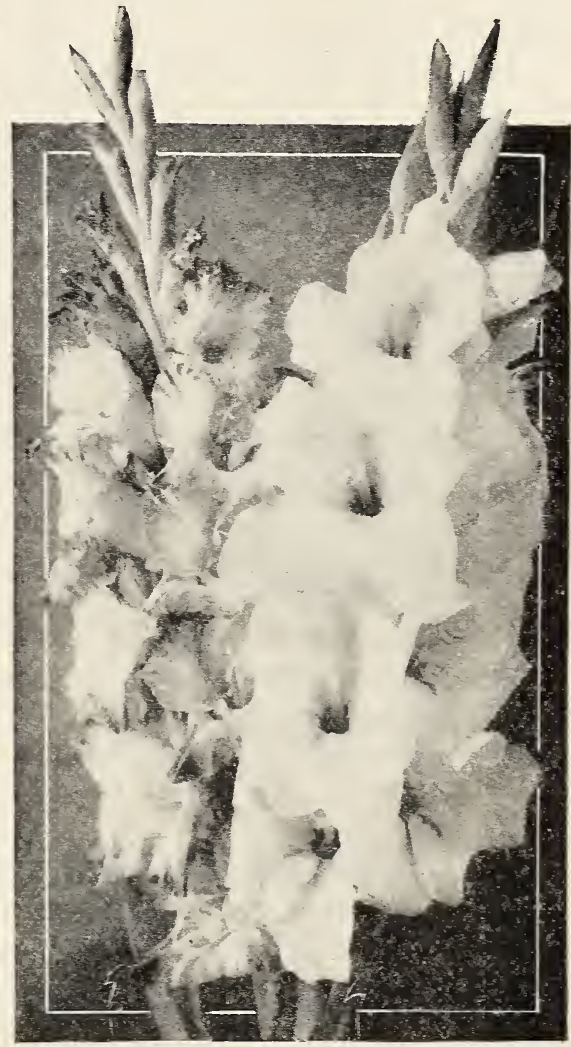

BUCKEYE-Large massive blooms of fine rose-pink color with tint of old rose on edge of petal. A beautiful large rosered throat. $20 \mathrm{c}$ each; $\$ 2.00$ dozen.

CRINKLES-Deep peach-blossom pink. Intensely ruffled. This creation is the best of the ruffled variety in the deeper pinks. Each 30c. 


\section{GLADIOLUS BULBS (Comtinued)}

DREAM - Large blooms of deep crimson red; very showy blotches. A grand flower. 20c each; $\$ 2.00$ dozen.

E. J. SHAYLOR-Tall, ..very ...strong plant with large blooms. A beautiful, pure deep rose-pink. Very choice. 10c each; $\$ 1.00$ dozen.

FERN KILE-A large ruffled flower of creamy white color. A sensation wherever shown. A Kundred creation. 15c each; $\$ 1.50$ dozen.

GOLDEN GLORY-A large richly colored yellow; well ruffled, with a perfect throat. $15 \mathrm{c}$ each; $\$ 1.50$ dozen.

LILAC GLORY-Large flowers and many open at a time; soft lilac rose pink, beautiful deeper rose pink throat. Each 25c

MARIE KUNDERD-A wonderful, very early, pure white Glad with an almost invisible soft pink line in center of lower petal. Grandest of all whites. 35c each; $\$ 3.50$ dozen.

MARSHAL FOCH-Many giant flowers open at a time on strong stems. Color finest salmon pink. $15 \mathrm{c}$ each; $\$ 1.50$ dozen.
ORANGE GLORY-Rich, orange of wonderful brilliancy, petals finely ruffled. Large individual flowers. A fine new one. $10 \mathrm{c}$ each; $\$ 1.00$ dozen.

PURPLE GLORY-The giant of the Kunderd Glory Race. Deepest, velvet, purplish, maroon red, with almost black blotches. Beautifully ruffled. 15c each; $\$ 1.50$ dozen.

ROSALIND-Dark analine red with deeper throat distinct and grand; often mentioned as one of the most beautiful Glads. 25c each; $\$ 2.50$ dozen.

ROSE ASH-Corinthian red shaded to ashes of roses at edge of petal; large ruffled flowers well set on the spikes. Very distinct and beautiful. 15c each; $\$ 1.50 \mathrm{doz}-$ en.

SCARLANO-This is a fine ruffled sort with large fine scarlet flowers. 10c each; $\$ 1.00$ dozen.

VIOLET GLORY-Massive flowers; rich self-colored deep violet; deeper throat. Medium ruffled. Each 25c.

W H I T E GLORY-A ..gorgeous ..pure white type of Glad with beautiful iris-blue throat. A grand ruffled sort. 20c each. $\$ 2.00$ dozen.

COLLECTION NO. 23-One each of listed Ruffled Glads, (19 in all) regular value $\$ 3.40$. All for $\$ 2.95$.

COLLECTION NO. 24-One each of the 10c and 15c Ruffled Glads, 10 in all, (regular price $\$ 1.30$ ) for $\$ 1.10$.

COLLECTION NO. 25-One each of the 20c, 25c and $30 \mathrm{c}$ ruffled Glads, 9 in all, (regular value $\$ 2.10$ ), for $\$ 1.90$.

\section{Primulinus Hybrid Gladioli}

This race of Gladioli has been produced $\leftrightarrow$ famous. Capucine orange slightly tinted by using the fine yellow species "primulinus" in crossing with other existing strains. The varieties resulting are distinguished for their fine and varying shades of yellow, orange, saffron and pastel tints, graceful, slender stems.

ALICE TIPLADY - A grand, large primulinus of most beautiful orange-saffron color. 10c each; $\$ 1.00$ per dozen.

GOLD DROP $-A$ very attractive and beautiful shade of yellow. Flowers large and artistic on graceful spikes, 10c each; 90c per dozen.

ORANGE PRINCE-One of those colors among the prims which have made them with deeper orange. 10c each; $\$ 1.00$ dozen.

JEWELL-A very beautiful shade of pink; throat yellow. One of the very best. 15c each; $\$ 1.50$ per dozen.

MID-SUMMER DREAM-Large beautiful geranium red. Grand showy flower. 15c each; 1.50 per dozen.

PARMA-Soft rose-pink and cream. Exceedingly pure, finely colored variety. 20c each; 2.00 per dozen.

WHITE BUTTERFLY-A first class all-white with soft cream-white throat, slender stem and beautiful cut flower, 15c each; 1.50 per dozen.

COLLECTION NO. 30-One dozen mixed Primulinus hybrid for 40 s. 


\section{Plain Petaled Gladioli}

AMERICA-A fine soft pink flower on: fine stems and is a favorite of the plain petal sorts; each $5 \mathrm{c}$; $50 \mathrm{c}$ dozen.

ANNA EBERIUS-Rodamine purple, selfcolored except for a deep amaranth blotch on lower petal. One of the best of the large purple sorts. 10c each; $\$ 1.00$ dozen.

BARON HULOT-Rich royal violet-blue. Flowers are medium in size, well placed and borne on strong spikes. 10c each; $\$ 1.00$ dozen.

BLACK PANSY-Rich dark red; beautiful pansy-like throat. Extra good. A general favorite. Flowers large. 15c each; $\$ 1.50$ dozen.

BLUE JAY-Bluish-lavender shading lighter in the throat. Lower petals have a pansy-purple blotch tipped with cream. very graceful. 15c each; $\$ 1.50$ dozen.

BYRON L. SMITH-One of the very best. Most refined lavender-pink on white ground. Exceedingly fine for cut flowers. 10c each; $\$ 1.00$ dozen.

CHALLENGER-A large vigorous plant; giant, dark, rich velvety red, solid color. An extraordinary fine variety. 15c each; $\$ 1.50$ dozen.

CRIMSON GLOW-Brilliant crimson, overlaid with darker shades; lower petals blotched with deep velvety crimson. The flowers are immense and striking. 10c each; $\$ 1.00$ dozen.

FLAMING VALE-Very tall; long spikes with large, deep cardinal-red flowers; throat a little deeper. Pure self-color effect. Exceptionally attractive. 15c each; $\$ 1.50$ dozen.

GOLD MEASURE-Pure Massoit yellow, self-colored; flowers large and well arranged. Many blooms open at a time. 15c each; \$1.50 dozen.
HALLEY-Delicate rose; large flowers and many blooms at a time. Very popular; magnificant. $8 \mathrm{c}$ each; 60c.dozen.

HERADA-Magenta shading to pink in throat; lower petals blotched with rose; flower well arranged. Unusually distinct and very showy. 5c each; 50c dozen.

IDA VAN $-A$ most beautiful salmonred or flaming orange-pink. A rich and brilliant color. $8 \mathrm{c}$ each. $75 \mathrm{c}$ dozen.

JOHN T. PIRIE-An exceptionaily colored variety; a sort of mahogany-brown with yellow bordered dark mahoganybrown throat. In a class by itself. Each $30 \mathrm{c}$.

KUNDERD'S YELLOW FAVORITEEntire face of the flower deep-yellow with deeper yellow on lower petals. Throat finely feathered and penciled soft-red. The plant is tall and stately. Each 35c.

MAINE-Pure glistening white without a blemish except very faint lavender feathering in throat. Tall straight spikes; best white ever introduced. $15 \mathrm{c}$ each; $\$ 1.50$ dozen.

MARY PICKFORD-An extraordinary flower of most delicate creamy-white; throat finest, soft sulphur-yellow. Exceptionally distinct and striking. 20c each; $\$ 2.00$ dozen.

MILLIONAIRE-Tall, elegant plant, many flowers open at a time; flowers rich velvety crimson, beautifully flaked geranium-red; lower petals flaked darker; throat deeper red with creamy blotches. Each $40 \mathrm{c}$.

MRS. FRANCIS KING-Jasper red with lower petals splashed with deeper red, throat lighter. Very large flowers well arranged. $8 \mathrm{c}$ each; 60c dozen.

\section{GLADIOLA BULBS FREE}

We have a surplus of Mixed Hybrid Gladiola Bulbs and if you are interested we will give, Free, one-half dozen with any order of garden Seeds amounting to $\$ 2.00$. We will give one half dozen Mixed Hybrid Gladiola Bulbs with any order of garden seeds amounting to $\$ 2.00$. Just mention it. 


\section{PLAIN PETALED GLADIOLI (Comininued)}

MRS. LEON DOUGLAS-A brilliant shade of begonia-rose, striped with scarlet. Conceded to be one of the best in its color. Flowers very large. 20c each; $\$ 2.00$ dozen.

NIAGARA-Nankin yellow, lower petals are deeper yellow with carmine feathering. Enormous blooms. 10c each; $\$ 1.00$ dozen.

PANAMA-Immense spikes of large rosy-pink flowers. One of the best and most popular. Late mid-season. $8 \mathrm{c}$ each; $60 \mathrm{c}$ dozen.

PEACE-Clear white with claret blotch on lower petals; feathered pale lavender. Very beautiful late white. 8c each; 60c dozen.
SCHWABEN-Marguerite yellow with carmine throat; very large flowers on straight spikes. One of the finest; late mid-season. 8c each; 60c dozen.

TIGER-Large perfectly placed, wide open flowers of tiger-like markings; ground color of deep smoky-blue; outer edge of petals finest salmon-red flaking; throat red with outer portions blotched with white. Each 50c.

ULYSSES-Large round flower smokeblue on rose-pink ground, deeper throat; very attractive. $15 \mathrm{c}$ each; $\$ 1.50$ dozen.

WILBRINK-Delicate peach-pink with creamy shadings; fine, easy grower and free bloomer. Wide open flowers on tall spikes. 5c each; 50c dozen.

COLLECTION NO. 22-One bulb each of these New Plain Petaled Glads; John T. Pirie, Kunderd's Yellow Favorite, Millionaire and Tiger. Regular value $\$ 1.55$; we offer the 4 for $\$ 1.30$.

\section{Special Offer on Gladiolus}

COLLECTION NO. 26-One bulb each of the entire twenty-seven Plain Petaled Glads, (value $\$ 4.13$ ), for $\$ 3.70$.

COLLECTION NO. 27 -One bulb each of the $5 \mathrm{c}, 8 \mathrm{c}, 10 \mathrm{c}$ and $15 \mathrm{c}$ Plain petaled Glads, (value \$2.18) 21 in all, for $\$ 1.95$.

COLLECTION NO. 28-One bulb each of the 20c 30c, 35c, 40c and 50c Plain Petaled Glads, (value $\$ 1.95$ ) six bulbs in all for $\$ 1.75$.

COLLECTION NO. 29-One bulb each of the Primulinus Glads, six in all (value $75 \mathrm{c}$ ) for $60 \mathrm{c}$.

COLLECTION No. 31-One dozen Gladiolus bulbs from named varieties, (our choice) a fine mixture $30 \mathrm{c}$ per dozen.

COLLECTION NO. 32-One dozen hybrid mixed Glads, all colors, 40c per dozen.

Knowing the germination period of the different kinds of seeds and with the testing apparatus we have, the Puget Sound Seed Company is able to guarantee all seeds to the full amount of the purchase price. 


\section{Da h 1 is a}

\section{CULTURE}

Dahlias will adapt themselves to any kind of soil if properly cared for. Their native soil is a sandy loam. If your soil is poor, it should be built up in the fall with some good fertilizer, then at planting time a handful of bone meal thoroughly mixed with the soil and placed in each hole, is very beneficial.

In this climate Dahlias can be planted from April until June, but we prefer the latter part of April. Our bulbs are ready for delivery after April 15. Plant two to three feet apart in holes from four to six inches deep, laying bulb flat with the eye uppermost. Never stand bulb on end. ing.

Keep the scil well worked until buds appear, after which keep the soil from crust-

Do not water until the plant appears above the ground; it may cause it to rot. When watering, thcroughly soak the ground; do not sprinkle the surface.

\section{CACTUS DAHLIAS}

ALEX KENNEDY - Large deep crimson flowers on fine stems …..........

AMBER GLOW-Bright yellow deepening to orange $\quad 50 \mathrm{c}$

AUBURN BEAUTY-Bronze and yellow …

BALLET GIRL-HC Orange and white ............50

BIZZAIRE-Rare shade of carmine purple, white tipped, much incurved ............ $35 \mathrm{c}$

BORDER KING-Large incurved flower of rich deep glowing scarlet.......................50

CALIFORNAA ENCHENTRESS-HC Fine pink flower on large size stems, erect

free flowering ................... $50 \mathrm{c}$

CARONIA-Large deep yellow .................... $50 \mathrm{c}$

CONSTANCE-Pale amber tinted cherry-red, very large $\ldots \ldots \ldots$

DADDY BUTLER-HC Giant flowers on long stems, rose carmine shade with lighter reverse

EDITH CARTER-Yellow tipped with carmine, erect stems

F. W. FELLOWS-Giant orange cactus on good stems, slightly incurved ……....... $40 \mathrm{c}$

GEN. SMITH DORIEN-Large and incurved flower of bright scarlet ……..............50c

GEN. WALTERS-HC Very large and free, shades of salmon and rose _.............50

GOLDEN WEST-Golden amber, one of the finest to cut, free on good stems .......50c

GUARDIAN-Glowing crimson scarlet ..................

HUGH McNEIL-A distinct shade of pink, long erect stems

IRRESISTABLE-Rose shaded to yellow, fine ……

IVORY WHITE-Cream white flowers on good stems

J. H. JACKSON-The finest black cactus in existance, very satisfactory, blackish maroon

JOHN RIDING-Deep rich crimson. very large, incurred petals, strong stems ............35c
J. W. HERSHEY - Glowing salmon rcse tipped with gold

JUPITER-Pink and yellow. striped with maroon

KALIF-HC Gigantic flowers of brilliant scarlet carried erect on long strong stems 45c

KRIMHILDE-HC Deepest pink shading to white in center, late flowering …….......25c

MAGNIFICENT_HC Orenitl buff, overlaid rosy salmon, large and free ....................35c

MILTON HOWARD-A charming shade of bright pink with white center and tips of petals

MELODY-Cleat yellow tipped with white, on long stems

Mrs. W. E. ESTES-HC The finest pure white hybrid cactus. large and on fine stems $40 \mathrm{c}$

MRS. MARGARET STREDWICK-Pink, beautifully incurved. free .........................50c

MRS EDNA SPENCER-HC Pale lilac, fine incurved form. large on strong stems ...50c 


\section{CACTUS DAHLIAS (Cominnued)}

MME. LE BRUN-The darkest violet-purple, free on good stems ……........................35c

NEW MOON-HC. Canary yellow tipped with white ...................................................

NIBELUNGENHORT-HC. Ole rose tinted apricot, always a favorite for cutting very large, free

OLIMPIC-Scarlet, much incurved, very fine

PERLE de $\mathbf{L Y O N}-$ HC. Pure white; petals fringed or nicked giving a unique appearance

PENNANT-Beautiful clear coral, on fine stems

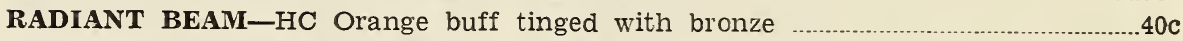

RHEINISHER FROHSINN-Carmine rose, base white, very popular for cutting ........50c

RICHARD BOX-Light yellow, free blooming on strong stems …...................................50c

RICHARD BOZE-A dark red cactus flowered dahlia with good stems ........................50c

RUTH VAN FLEET-HC. Large full flower of sulphur yellow on long erect stems ....40c

RUTH GLEADEL-HC. Giant blooms on long stems; yellow shading to an apricot bronze

ST. LEONARD-Yellow tipped scarlet, good stems

STERNA-Beautilul, semi-cactus, white with a yellow tipped at the base of each petal. Extra fine for floral work. Free bloomer of medium size

SWEET BRIAR-Pure pink

SOLDIER LASS-Bright red tipped with pure white, on good stems …….................45c

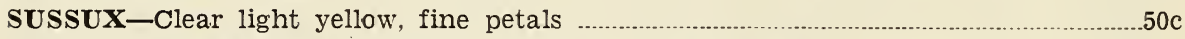

VICAR OF WAPERTON-Shades of pink and of good form …................................

VULCAN-Maroon with white florets at base of petals, large on good stems _..........50c

WALKURE-HC A giant on strong stems; sulphur deepening to gold at center ........50c

YELLOW KING HC. Giant flowers on tall erect stems; yellow shading to lighter at tips

\section{COLLECTION NO. 33}

One each Cactus Dahlia, not named, Red, White, Pink and Yellow, 4 in all 60c

\section{DECORATIVE DAHLIAS}

AL KORAN-A giant on long erect stems; goldenrod yellow, suffused amber on older petals

ASTERFLORA-Clear deep pink resembling an aster, large flowers on strong stems 50c

ALBERT MANDA-A decorative dahlia of medium sized blossoms of a delicate shade of yellow lightly flushed with carmin-lavender shading. Very odd and distinct.

BESSIEBOSTON-A large cardinal red flower on strong stems; the petals,are divided at tips

BEN WILSON-Bright buff, heavily shaded with rich red, tipped yellow, very large 35c

BLACK BEAUTY-One of the darkest of this type; flowers of perfect form on long stiff stems

CATHERINE COOPER-A beautiful rose-lavender

DR. H. TEVIS-Oid rose shading to gold; gigantic flowers on erect stems …...........45c

ENCHANTRESS-A wonderful silvery pink flower on fine stems ..................................50c

EXMOUTH GLORY-Apricot orange and white; free on strong stems ......................40c

GEO. E. WRIGHT-Salmon rose, suffused orange with mauve reverse, large with perfect stems

IMLMENSE-White streaked with crimson; stands erect ...................................................35c

INSULINDE-Rich golden bronze on long erect stems 
JANE SELBY-Immense delicate mauve pink on strong stems ....................................

KING ALFRED-Lavender slightly suffused with white ..................................................40c

MADONNA-Large ivory white flowers on extra strong, upright stems ........................35c

MAMON ROZIAN -White suffused with rosy-purple ….................................................35c

MARCELLA GILL-Extra early and one of the best cut flower dahlias; soft seashell pink with lighter tones

MILLIONAIRE-Gigantic flowers on strong stems; light lavender shading to a white at the center

MRS. CARL SALBACH-Extra long, strong stems carry monster flowers of mauve pink

MT. RAINIER-Bright yellow and scarlet

OREGON BEAUTY-The flower opens full but later shows a peony center; brilliant firey scarlet overlaid with a golden sheen

PAUL MICHAEL-Immense orange buff with rose shadings, fine stems .....................45c

PORTHOS-Violet with a blush sheen ...............................................................................75c

POLAR BEAR-A large snow-white flower on long stems, fine for cutting ................40c

RIVERSIDE-Cream overlaid with rosy pink; beautiful form on long stems ............50c

ROSE NELL-Clear, bright cerise-rose; gigantic blooms on strong erect stems .........50c

ROSEMWAR-Soft rose pink. Very large and free on long stems ...........................50c

SENORITA-A giant flower on good stems. The color is a rich velvety crimson; long pointed petals

SHUDOW'S LAVENDER_Very large silver lavender blooms on perfect stems ........75c

TRYPHINNIE-Shell pink shaded lighter at the tips

\section{COLLECTION NO. 34}

Decorative Dahlias, not named; cne each color of six different shades $90 \mathrm{c}$

\section{PEONY FLOWERED DAHLIAS}

ARTIC-A giant often 9 inches across; pure white blooms on good stems ....................50c

BILLIONAIRE-A monster flower of golden orange .....................................................40c

CITY OF PORTLAND-The flowers are unusually graceful; the color is a clear

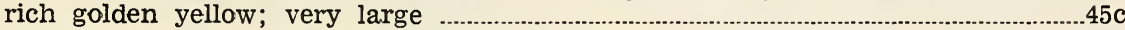

DR. PERRY - Gigantic flowers of reddish mahogany; very attractive..............................25c

FLUFFY-Large delicate buff pink, fluffy irregular flowers, very attractive ................25c

GORGEOUS-Yellow shading to a scarlet ............................................................................75c

GLORY OF NYKIRK-Giant blooms on long, strong stems; purple, lightly shaded maroon

HI GILL_Golden yellow, reverse bronz, large flowers on long strong stems ................35c

JAMES C. GILL-One of the finest for cut flowers; bright golden yellow; marked and toned with red

MEYERBEER-Giant flowers on strong erect stems; dark crimson, toned purple ....50c

PEARL RUGGLES-Carmine rose shading to a light pink at tips

PRIDE OF PORTLAND-Geisha colors but of brighter yellow and richer red; long erect stems

THE ORIOLE-Combination of burnt orange, red and yellow, sometimes tipped white

VAN DYKE-Mammoth twisted flower; salmon rose, tinted heliotrope, long stems 50c

COLLECTION NO. 35

Peony flowered Dahlias, not named, one tuber each of 6 different colors 90c 


\section{SHOW DAHLIAS}

CLARA SEATON-Enormous flowers of a rich golden yellow …..............................35c

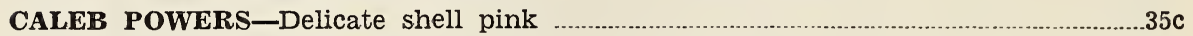

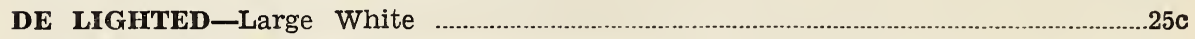

DREERS YELLOW-Large quilled flowers of a clear rich yellow ..................................35c

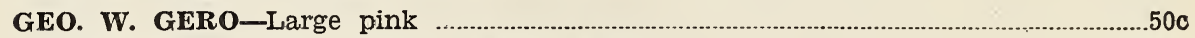

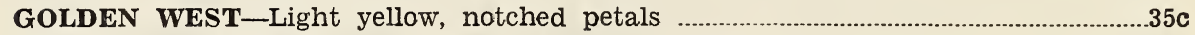

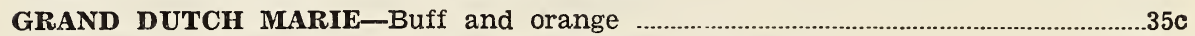

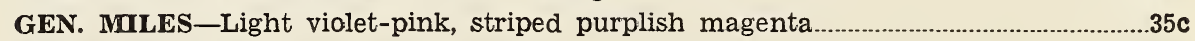

HELEN HOLLIS-Large, deep scarlet ................................................................................25c

ROBERT BLOOMFIELD-Pure white .........................................................................25c

W. W. RAWSON_Large quilled flower, white overlaid with lavender ...........................35c

COLLECTION NO. 36

One tuber each of Clara Seaton, Dreer's Yellow, Gen. Miles, Helen Hollis and

W. W. Rawson, five in all for $\$ 1.40$

\section{POM POM DAHLIAS}

25 c each or 2.50 per dozen

ACHILLES-Shell pink.

ADRIENNE-Scarlet tipped yellow.

AMBER QUEEN-Golden yellow

BLANCHE GRAY-Deep lemon

BOBBY-Plum color

BRUNETTE-Crimson tipped pink

DARKEST OF ALL-Deep Maroon

DAISY_Salmon rose

FASCINATION-Pink tipped lavender

GEO. IRELAND-Pure mauve.

JESSICA-Buff shaded red
JIM DYBLE-Brick red

LASSIE-Yellow shaded rose.

LITTLE JENNY-Primrose yellow

LADY BLANCHE-Fine white

MADELINE-Primrose edged rose carmine MIDGET-Soft salmon peach pink

PRINCE CHARMING-Cream tipped purple

TOMMY KEITH-Cardinal red tipped white

WINNIFRED-White tipped lavender.

\section{COLLECTION NO. 37}

One tuber each Adrienne, Amber Queen, Brunette, Fascination, Jessica, Lassie,

Little Jenny, Lady Blanche, Prince Charming and Winnifred, 10 in all for $\$ 1.90$

\section{SPECIAL DAHLIA OFFER}

COLLECTION NO. 38-A collection of Dahlias that the name and class tags have been lost and we will offer ten (10) of them for $\$ 1.00$

\section{FREE OFFER}

One only Dahlia, our choice, with any order of vegetable or flower seeds amounting to $\$ 1.50$ or 6 Glads with an order of $\$ 2.00$ 


\section{GRASS AND FIELD SEEDS}

All prices listed on Grasses and Field Seeds are subject to change without notice and when overpayments are sent in refunds will be made promptly; these prices are for the first and second zones only. Write for prices on large quantities. Only the highest grade of seed used.

ALFALFA-Sow ten to fifteen pounds to the acre. Per pound $40 \mathrm{c} ; 10$ pounds $\$ 4.00$.

ALFALFA, "Grimm"-Hardier and better, sow 10 to 15 pounds to the acre. Per pound $50 \mathrm{c} ; 10$ pounds $\$ 4.50$.

ALSIKE-CLOVER-Fine in mixtures with other grasses. Sow 8 to 10 pounds to the acre. Per pound $45 \mathrm{c} ; 10$ pounds $\$ 4.00$.

RED CLOVER, Medium-The standard clover Ior all purposes. Sow 10 to 12 pounds per acre. Per pound 50c; 10 pounds $\$ 4.50$.

MAMMOTH RED CLOVER-Used largely to plow under for green manure. Sow 10 to 12 pounds per acre. Per pound $50 \mathrm{c}$; 10 pounds $\$ 4.50$.

TIMOTHY-One of the most used of all grasses for hay. Sow 12 to 16 pounds to acre. Per pound 20c; 10 pounds $\$ 1.30$.

MEADOW FESCUE-Perennial, good for pastures and fine to mix; sow 25 to 30 lbs. to the acre. Per pound $40 \mathrm{c} ; 10$ pounds $\$ 3.50$.

ORCHARD GRASS-One of the earliest and best producers in the grasses. Sow 35 to 45 pounds to the a.cre. Per pound $35 \mathrm{c} ; 10$ pounds $\$ 3.00$.

ITALIAN RYE GRASS-Quick growing and desirable for temporary pastures; sow about 40 pounds per acre. Per pound $25 \mathrm{c} ; 10$ pounds $\$ 2.00$.

ENGLISH RYE GRASS, Perennial-It is equally valuable for grazing and hay. Sow about $40 \mathrm{lbs}$. to the acre. Per pound $25 \mathrm{c} ; 10 \mathrm{lbs}$. $\$ 2.00$.

RED TOP-A good perennial for permanent lawns and pastures. Sow about 12 pounds per acre. Per pound $40 \mathrm{c}$; 10 pounds $\$ 3.00$.

CHEWING FESCUE-A low growing grass and permanent in all soils; used in mixtures for lawns and golf courses. When sown alone use about $25 \mathrm{lbs}$ to the acre. Per pound $45 \mathrm{c} ; 10 \mathrm{lks}$. $\$ 4.00$.

KENTUCKY BLUE GRASS-Used in nearly all lawn mixtures and in permanent pastures. Sow about 20 lbs. per acre. Per pound 50c; 10 lbs $\$ 4.50$.

WHITE DUTCH CLOVER-Superior for pastures and in lawn mixtures. Per pound $50 \mathrm{c} ; 10$ pounds $\$ 4.50$.

CREEPING BENT-Makes one of the best lawn grasses and we use it in all of our mixtures. Per pound $\$ 1.10 ; 10$ pounds $\$ 10.00$.

SEASIDE CREEPING BENT-This is the highest quality of the Bents and is offered in certified and sealed bags. Per pound $\$ 2.50 ; 5$ pounds $\$ 11.00 ; 10$ pounds $\$ 21.00$.

FOR FORAGE CROP

DWARF ESSEX RAPE-Fine for chickens; per pound 20c; 10 pounds $\$ 1.50 ; 50$ lbs. $\$ 7.50$.

\section{REFERENCE TABLES}

Quantities of Seeds to Produce a Given Number of Plants or to Sow an Acre

\section{VEGETABLE SEEDS}

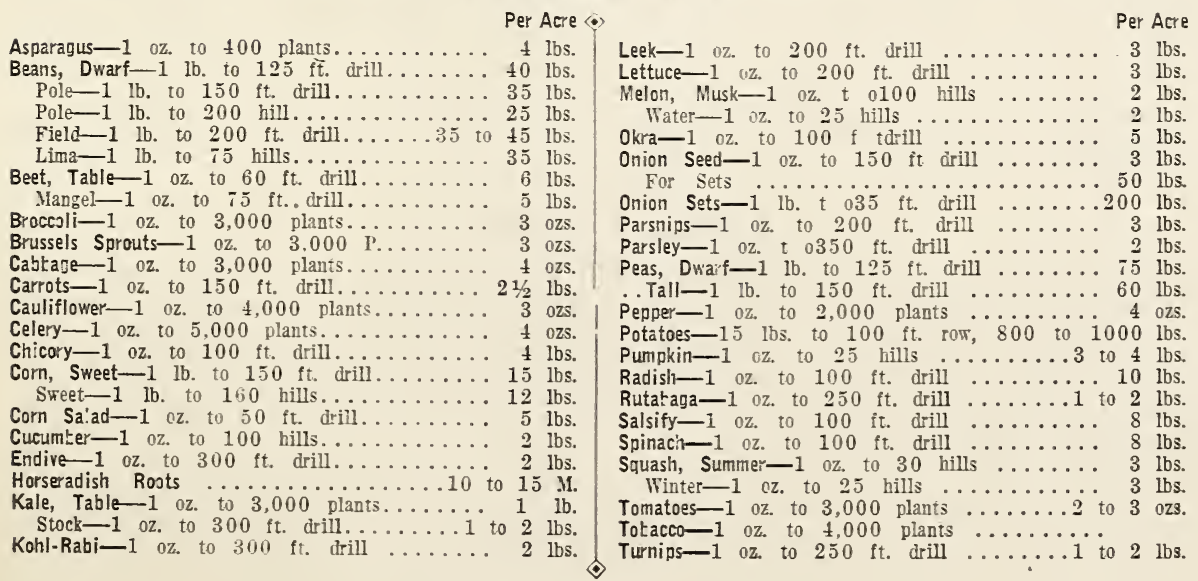




\section{FERTILIZERS}

Use fertilizer to beautify your lawns, flower beds and gardens If you want a big a big crop, beautiful flowers and gardens, you must be careful of several things. In the first place, select your seed from a responsible dealer, as no growth can be secured if seed are without life. Next, gt th sed bd in shape by spading deep, pulverizing the lumps, and enriching with the right kind of fertilizer. No soil is so rich that it can produce year after year unless some of the food which the plant "eats" is replaced. Fertilizer is necessary, but what kind?

\section{Garden and Lawn Fertilizer}

"Magnolia" is a high-grade, well-balanced fertilizer, made of pure chemical and organic substances. It is particularly adapted to flowering annuals, shrubs, small fruits, deciduous trees, vegetables, truck crops, kitchen gardens, potted flowers and window boxes. It is free from disagreeable odors and weed seeds.

Price: 5 -lb. carton, $65 \mathrm{c} ; 10-\mathrm{lb}$. bags, $\$ 1.25 ; 25-\mathrm{lb}$. bags, $\$ 2.00$. Postpaid in the first and second zones only. Write for prices on other amounts.

\section{Magnolia Fertilizer}

Analysis: Nitrogen, 5 per cent; Phosphoric Acid 6 per cent; Potash, 8 per cent.

"Magnolia" Fertilizer is a well-balanced chemical fertilizer, suitable for flowers, roses, gardens, etc. If the lover of flowers, roses and lawns will use care in using "Magnolia", he will find its purchase has been one of the best investments he has ever made in the way of satisfaction in results secured.

Price: $25-\mathrm{lb}$. bag, $\$ 1.50 ; 50-\mathrm{lb}$. bag, $\$ 2.50$; not postpaid. Write for smaller or larger quantities.

\section{FIELD ANALYSIS}

"Magnolia" Fertilizer-Field Analysis 3-10-2, 100-lbs. \$2.60, f. o. b. La Conner, Wash. "Magnolia" Fertilizer-Field Analysis 3-10-8, 100-1bs. \$3.50, f. o. b. La Conner, Wash.

\section{Lawns-New}

The soil should be well spaded and thoroughly raked, making sure that the soil is in a very fine condition for at least 3 inches deep. Then roll the surface so that it is smooth.

Then apply MAGNOLIA fertilizer at the rate of $100 \mathrm{lbs}$. per 1,000 sq. ft., making sure that it is evenly distributed over the surface. Then rake it in. Sprinkle with a fine spray and let stand for a few days.

Then plant the best grass seed you can get by raking it in.

UNDER NO CONDITION MIX THE SEED AND FERTILIZER TOGETHER BEFORE PLANTING.

\section{Lawns-0ld}

Water the lawn so that the ground is wet to a depth of 4 or 5 inches, then apply MAGNOLIA Fertilizer at the rate of 25 or $30 \mathrm{lbs}$. per 1,000 sq. ft., making sure that it is evenly distributed over the lawn. After this is done, sprinkle the lawn well again to make sure that the fertilizer gets down in the ground before it burns the grass. Should you notice any burning effect, water the lawn well, and the grass will be nice and green.

If you receive more than one copy of our Seed Annual hand the extra one to a friend. 
VEGETABLE SEED

Asparagus

Asparagus (plants)

Beans (all varieties)

Beets (table, sugar, cow)

Cauliflower

Cablcage

Carrots

Celery

Cress

Corn Salad

Corn, all kinds

Cucumbers

Chicory

Dill

Endive

Herbs

Kohl Rabi

Leek

Lettuce

Melons (musk and water)

Onicn Sets

Onion Seeds

Parsnips

Parsley

Peas

Peppers

Pumpkins
INDEX

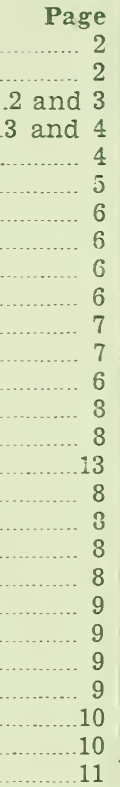

Rutabaga .12

Radishes

Salsify

Sunflower 11

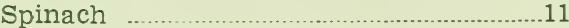

squash

Tcmatoes

Turnips 12

Tcbacco

PLANTS

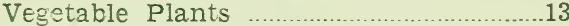

Ficwer Plants

Flower Seed ….................................... to 22

Sweet Peas …………..................................... 15

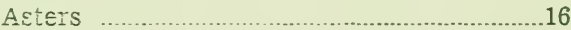

Gladiolus ............................................ 23 to 26

Dahlias ................................................... 37 to

Fertilizers 32

Grass and Field Seed ……............................ 31

Excepticnal Spencer Sweet

Pea collection

- Special -

Gladiolus Offers

Dcn't miss our big offers in

Dahlias

27 to 30
OUR MONTHLY

Artichoke-Globe

Asparagus-all varieties

Beans-Bush

Pole.

Beet-Early

Late

Broccoli

Brussels Sprouts

Cabbage-Early

Late

Carrot-Early

Late

Cauliflower-Early

Late

Celery-Early

Late.....

Chervil

Chicory

Chives

Collards

Corn-Sweet, Early

Sweet, Late

Corn Salad

Cress

Cucumber

Egg Plant

Endive

Herb Seeds

Horseradish

Kale

\section{PLANTING} Open Ground Mar. \& Apr. Mar. to May May to July May \& June Mar. \& Apr. Apr. to July Avr. to June Apr. to June

Apr. \& May Mar. \& Apr Apr. to June

May \& June

Apr. \& May Apr. \& May Apr. \& May Mar. \& Apr. Apr. \& May May \& June May to July Apr. to June Mar. to June May to June Apr. to July Apr. \& May May \& June

ALENDAR FOR VEGETABLES

Kohl Rabi

Leek

Lettuce-Early Late

Mangels-Sugar

Melon

Mustard

Okra

Onion-for dry onions

Onion Sets-for bunching

Parsley

Parsnips

Feas-First Early Second Early

Late

Pepper

Pctatces

Pumpkins

Radish-Early

Winter

Rhubarb

Rutabaga

Salsify

Spinach

squash-Summer

Fall and Winter

Tobacco

Tomato

Turnip-Early

Late
Open Ground

Apr. to June Mar. to May Mar. \& Apr. Apr. to Aug. Apr. to June May \& June Mar. to Oct. May \& June Mar. to May Mar. to Oct. Mar. to June Mar. to June Oct. \& Nov. Mar. to July Apr. to July Apr. to July May \& June Apr. to Sept. May to Sept. Apr. \& May Apr. \& May Apr. to June Apr. to Oct. May \& June May \& June

Mar. to May Apr. to Sept. 


\section{One}

\section{Dahlia Tuber}

(OUR CHOICE)

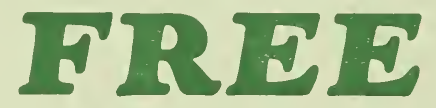

With each order of Seed Packets amounting to $\$ 1.50$

Read our collection offers of Dahlia You'll be interested

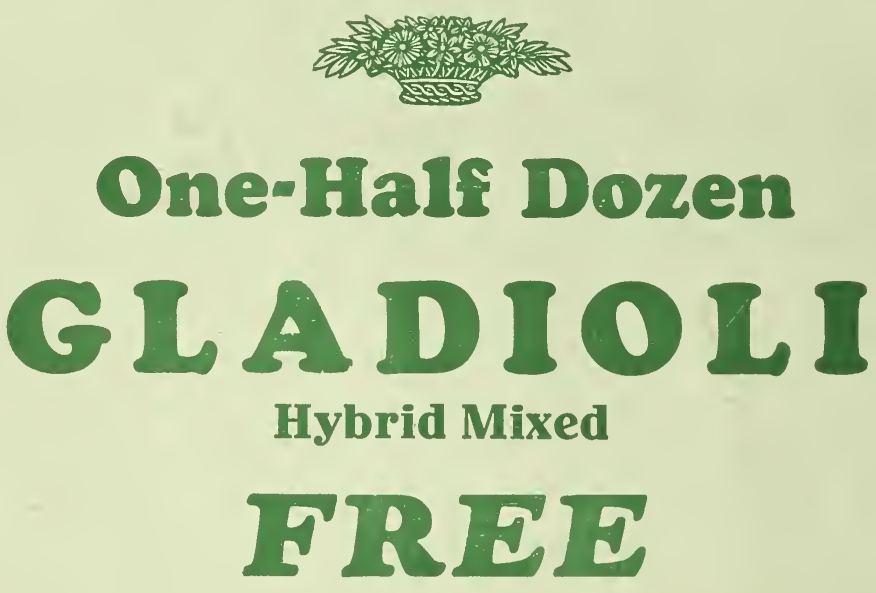

With each order of Seed Packets amounting to $\$ 2.00$.

See our Gladiola Collection Offers Numbers 20 to 32 . Thirteen separate collections of exceptional value.

\section{Puget Sound Seed Co.} LaConner, Washington 